\title{
Disentangling the Multiple Effects of Affiliate Reputation on Resource Attraction in New Firms
}

\author{
TOM VANACKER \\ Ghent University \\ Faculty of Economics and Business Administration \\ Sint-Pietersplein 7 \\ 9000 Gent \\ BELGIUM \\ Tel: +32 92647960 \\ Fax: +32 92643577 \\ e-mail: TomR.Vanacker@UGent.be \\ DANIEL P. FORBES \\ University of Minnesota \\ Carlson School of Management \\ 321 - 19th Ave. South, Suite 3-365 \\ Minneapolis, MN 55455 \\ USA \\ Tel: +1 6126252989 \\ Fax: +1 6126261316 \\ e-mail: forbe010@umn.edu
}

Accepted version dated June 1, 2016. Published in 2016 in Organization Science.

https://doi.org/10.1287/orsc.2016.1090

Citation for the published version: Vanacker, T. \& Forbes, D.P. 2016. "Disentangling the multiple effects of affiliate reputation on resource attraction in new firms.” Organization Science, 27(6): 1525-1547.

(C) 2016. This manuscript version is made available under the CC-BY-NC-ND 4.0 license http://creativecommons.org/licenses/by-nc-nd/4.0/

Acknowledgements. We are grateful to Erkko Autio, Frédéric Delmar, Gary Dushnitsky, Martin Ganco, Aseem Kaul, Mirjam Knockaert, Hans Landström, Jiao Luo, Sophie Manigart, Chris Nachtsheim, Tim Pollock, Akshay Rao, Peter Roosenboom, Harry Sapienza, Myles Shaver, Aaron Sojourner, PK Toh, and Mary Tripsas, among others, for helpful feedback. This paper further benefited from presentations at The Sol C. Snider Entrepreneurial Research Center (The Wharton School), the 2010 Academy of Management Meeting and the 2012 Strategic Management Society Conference. The first author gratefully acknowledges the financial support of the Hercules Foundation (AUGE/11/13) and the Research Foundation - Flanders (FWO11/PDO/076). 


\title{
Disentangling the Multiple Effects of Affiliate Reputation on Resource Attraction in New Firms
}

\begin{abstract}
Past research has established that new firms can enhance their attractiveness to prospective resource providers by affiliating with more reputable firms. But research on this process has yet to fully account for two critical realities underscored by recent research: 1 ) firms need to acquire resources from different groups of resource providers and 2) reputation is multidimensional. Drawing on the organizational reputation literature and on information processing theory, we propose that two groups of resource providers will respond differently to new firms' affiliations in accordance with differences in the groups' abilities to recognize and interpret reputation-related signals. We also propose that within a single group of resource providers, distinct characteristics of the affiliate will exert different influences. We test these propositions using longitudinal data from Belgian firms that affiliated with venture capital (VC) investors. Consistent with our predictions, we find that characteristics of a VC affiliate exert more influence on prospective financiers than on prospective employees. We further find that prospective financiers were more influenced by a VC's industry-specific experience than by its media prominence, whereas prospective employees were more influenced by a VC's media prominence than by its industry-specific experience. Taken together, the findings show that new firms' resource attraction trajectories are shaped by their affiliates in more complex ways than past research has accounted for.
\end{abstract}

\section{Introduction}

A key challenge firms face is that of attracting resources (Stinchcombe 1965). This challenge is especially acute for new firms, because they often possess few resources and face liabilities of newness (Aldrich and Ruef 2006). Thus, new firms must find ways to attract resources quickly to ensure their survival in the face of intense evolutionary pressures. Among the drivers of firms' resource attraction trajectories, reputation is critical insofar as it reduces the uncertainty prospective resource providers face in evaluating firms (Rindova et al. 2005). Extensive research shows that a firm's reputation increases its attractiveness for prospective resource providers (e.g., Gatewood et al. 1993, Shane and Cable 2002). However, new firms often lack a reputation and the resources needed to invest in reputation-related signals (Petkova 2012, Williamson 2000). In these cases, new firms can "borrow" the reputation from more established firms through affiliations with them (e.g., Gulati and Higgins 2003, Reuer et al. 2012, Stuart et al. 1999).

However, studies of reputation-borrowing by new firms have yet to account for two important realities underscored by recent research. First, past reputation research has generally explored how reputation influences the acquisition of resources from one particular group of resource providers—typically 
financiers (e.g., Petkova et al. 2013, Pollock and Rindova 2003, Stuart et al. 1999). But firms often need to simultaneously attract resources from distinct groups of resource providers, and there is increasing recognition that perceptions of a firm's reputation may vary across observers (Jensen et al. 2012, Lange et al. 2011, Rhee and Valdez 2009). Second, firms do not possess a single reputation-rather, reputations encompass distinct dimensions (Lange et al. 2011, Rhee and Valdez 2009). For example, Rindova et al. (2005) argue that reputation comprises two dimensions, which they characterize as "perceived quality" and "prominence”. But although the multidimensional nature of firm reputation is now widely recognized in theoretical writings, it remains empirically underexplored (Jensen et al. 2012). These theoretical developments raise unanswered questions about whether and how the multidimensional reputations new firms borrow from their more established affiliates affect their abilities to attract specific resources.

In this study, we ask the following research question: Do different groups of prospective resource providers respond differently to the reputation-related signals conveyed by an affiliate's characteristics? We propose a theoretical answer to this question by drawing on the reputation literature and on information processing theory. In particular, we propose that groups of resource providers will respond differently to new firms' affiliations in accordance with differences in their abilities to recognize and interpret reputationrelated signals, differences which in turn are a function of their accumulated domain-relevant expertise and the richness of their task-relevant information environments. We further propose that the expertise and information environment of a group of resource providers can be used to predict how that group will respond to specific affiliate characteristics.

We test our claims using unique longitudinal data from 94 Belgian firms that affiliated with venture capital investors (VCs). Like many growth-oriented firms, these firms needed to attract additional financial and human resources after an initial VC investment to pursue their growth ambitions (e.g., Davila et al. 2003, Gompers 1995). Our focus on Belgian firms facilitated our investigation in several ways. First, owing to Belgian reporting requirements, we were able to obtain detailed information on these firms' finances and employment for each year of the study. Such information is generally difficult to obtain for very young, private firms like those we studied (Robb and Robinson 2014). Second, Belgium, like many advanced 
economies, represents a moderately-developed entrepreneurial environment: It is developed enough to give rise to growth-oriented firms and to capital and labor markets capable of serving them, but it is not among the world's "hotbeds" of entrepreneurial activity. Accordingly, for reasons we explain below, it is a context in which the effects of reputation-borrowing are less likely to be confounded with alternative processes through which new firms sometimes attract resources on their own. Third, as we explain below, cultural and institutional features of the Belgian labor market make it especially challenging for new firms to attract skilled employees. Thus, although firms in many countries often struggle to attract talent (ECB 2009) ${ }^{1}$, these challenges are especially acute for Belgian firms. Taken together, these features of the Belgian context render it an appropriate "laboratory" in which to study how reputation-borrowing influences the attraction of financial and human resources in new firms.

Our findings show that two different groups of prospective resource providers (i.e., financiers and employees) respond differently to two distinct characteristics of a new firm's VC affiliate (i.e., the media prominence and industry-specific experience of the VC). Specifically, we show that a VC's industryspecific experience influences the attraction of financial resources more strongly than the attraction of human resources. In addition, we find that providers of financial resources are more strongly influenced by a VC's industry-specific experience than by its media prominence, whereas providers of human resources are more strongly influenced by a VC's media prominence than by its industry-specific experience. Additional tests show the robustness our findings.

This study makes several contributions. Our primary contribution is that we add to the stream of reputation literature concerned with the process by which new firms borrow the reputations of their affiliates (Petkova 2012). We extend that line of research by showing how reputation-borrowing depends on the successful transmission and interpretation of specific informational signals to specific groups of people

\footnotetext{
${ }^{1}$ Finding (skilled) employees is often a challenge even at times when average unemployment rates are high. In the U.S., for instance, statistics show that although more than 11 million people are unemployed, 4 million job openings remain unfilled. This suggests that firms frequently want to hire but struggle to find the right people (Dahl 2012). One reason is that unemployment rates vary widely across subgroups within a society; high average rates of unemployment often mask the fact that rates are significantly lower among educated workers (OECD 2013).
} 
outside the firm. More generally, by examining resource attraction longitudinally, our study responds to recent calls for reputation research to pay more attention to the processes by which reputation influences firm outcomes over time (Barnett and Pollock 2012, Love and Kraatz 2009).

\section{Background Literature}

\section{Reputation and Reputation-Borrowing by New Firms}

Scholars in several social science domains have shown longstanding interest in the concept of "reputation" and in how an organization's reputation influences its ability to attract resources (e.g., Lange et al. 2011, Rao 1994, Wilson 1985). There exist a number of alternative definitions of reputation (Barnett and Pollock 2012), but within the management literature most scholars have adopted a "sociocognitive" view of reputation, which regards organizational reputations as human interpretations or assessments rendered by “observers” in an organizational field (Barnett et al. 2006, Rindova and Fombrun 1999). Consistent with this sociocognitive view, we define reputation as “stakeholders’ perceptions about an organization’s ability to create value relative to competitors” (Rindova et al. 2005, p. 1033).

One stream of work within the reputation literature examines the role of reputation in new firms (Petkova 2012). Because reputations take time and resources to develop, new firms often lack strong reputations of their own; one way new firms respond to the "catch-22" challenge posed by their initial lack of reputation and resources is by affiliating with more established organizations that are perceived to be more reputable (Petkova 2012). These affiliations generate valuable informational signals that aid resource providers in distinguishing among firms (Jensen et al. 2012, Rindova et al. 2005). Specifically, the characteristics of a key affiliate influence resource providers to formulate perceptions regarding the reputation of that affiliate and, by extension, to draw inferences about the prospects of the new firm itself. Some sociocognitive studies of reputation measure reputation directly using ratings or rankings that capture observers’ perceptions or beliefs about a firm (e.g., Martins 2005, Rhee and Haunschild 2006), but studies of reputation-borrowing by new firms generally focus on affiliate characteristics instead (e.g., Lee et al. 2011, Stuart et al. 1999). Technically, the affiliate characteristics serve as antecedents of firm reputation, 
not direct measures of reputation; but, as Petkova (2012) observed, "the theorized mechanism through which affiliations affect performance outcomes is through the reputation borrowed from ... affiliates” (p. 385).

In her recent review of work on reputation in new firms, Petkova (2012) observed that there is a need for future research "to develop a richer and more nuanced understanding of ... the potential effects that the first reputation-granting authority may have on the reputation trajectory of a young firm” (p. 395). Our study responds to this need by explaining how a specific act of reputation-borrowing influences the firm's ability to attract the kinds of resources (e.g., people, funding) that the new firm could then invest in the development of its own reputation. We focus on how new firms borrow the reputations of VCs, in particular, because VC investment affiliations are often one of the earliest and most important ties formed by new firms that seek quick access to a variety of resources (Hallen 2008, Petkova et al. 2013).

Our study enriches our understanding of reputation-borrowing by examining two complexities that past research has left empirically underexplored. First, new firms often need to simultaneously attract resources from distinct groups of resource providers (Cooper et al. 1994, Davila et al. 2003), and there is increasing recognition that perceptions of a firm's reputation may vary across sets of observers (Jensen et al. 2012, Lange et al. 2011, Rhee and Valdez 2009). Consistent with this recognition, Jensen et al. (2012) contended that studies of reputation should examine "audience-specific assessments because actors play different roles that relate them to different audiences” (p. 148-149). Our study builds on this suggestion by considering how different sets of resource providers interpret the same reputation-related signals.

Second, reputation is a multidimensional phenomenon (Barnett and Pollock 2012, Rindova et al. 2005). In their review of the reputation literature, for example, Lange et al. (2011) summarized the three most common conceptualizations of firm reputation in this way: 1) "being known”, corresponding to observers’ general awareness of a firm; 2) “being known for something”, corresponding to observers’ assessments of particular firm attributes; and 3) "generalized favorability”, corresponding to observers’ overall perceptions of a firm as being good, attractive and appropriate. Petkova (2012) also invoked this three-part typology and proposed that the first two conceptualizations (i.e., awareness and assessment) are especially important to new firms. Yet, as Jensen et al. (2012) observed, although many studies "theorize 
the multidimensionality of reputation, they are less consistent in incorporating their theoretical arguments in the measurements of reputation", and they suggested that "future reputation research should examine different dimensions of reputation that coexist not only within a single actor but also within the same audiences” (p. 149). Our study builds on this suggestion as well by considering how different reputationrelated signals are interpreted by the same set of resource providers.

In the sections that follow, we propose that the ability of new firms to borrow the reputations of their affiliates is dependent upon the ability of specific observers to recognize and interpret the reputational signals conveyed by specific characteristics of the affiliate. Consistent with past research on reputation borrowing, we contend that observers are more likely to provide resources to new firms when they perceive that those firms' VC affiliates are reputable, and we focus on affiliate characteristics as antecedents to observers' reputational perceptions. However, we extend prior research by focusing on two dimensions of reputation: the perception that the VC is "known" and the perception that it is "known for something". We further contend that the process by which observers perceive an affiliate to be reputable with regard to either of these dimensions is not "automatic". Rather, we propose that: 1) observers must recognize and interpret the signals conveyed by a specific affiliate characteristic in order to formulate a reputational perception; and 2) the ability to recognize and interpret such signals is not uniform across observers. We develop these claims in the sections to come. But first we clarify the specific resource providers and dimensions of reputation with which our study is concerned.

\section{Prospective Financiers and Prospective Employees as Key Resource Providers}

In response to the need to consider how distinct audiences respond to new firms' reputation-borrowing affiliations, we focus on the attraction of financial resources from prospective financiers and human resources from prospective employees - two sets of resources that are critical for the emergence and early development of new firms (Cooper et al. 1994, Davila et al. 2003).

Prospective financiers, in this context, are providers of "follow-on" financing, or additional financing provided to a firm after an initial VC investment has been made. The initial investment may have 
been made by a single VC or a syndicate of VCs, where a "lead investor" takes the most important role in the initiation and governance of the investment (Wright and Lockett 2003). Follow-on financing is common in venture investing, because a single VC investment is seldom enough to successfully grow a new firm; rather, new firms are typically financed gradually in rounds, or stages (Gompers 1995). New rounds often involve the original VCs and one or more new VCs. Since follow-on financing may take the form of debt as well as equity, banks may also serve as financiers (Robb and Robinson 2014).

Prospective employees, in this context, are individuals willing to consider employment in a new firm. The hiring needs of VC-backed firms are diverse and variable, but they are likely to include a need for people who can help firms to further develop their technologies (such as engineers), people who can scale up the firm's production and sales capabilities (such as people with knowledge of operations, marketing or sales) and people who can help design and staff the administrative systems needed to support a growing organization (such as people with knowledge of accounting or information technology) (Baron et al. 2001, Flamholtz and Randle 2007). In addition, new firms are likely to require a mix of highly-skilled and lessskilled people within these various capacities (Cardon and Stevens 2004).

Prospective financiers and employees both have a strong interest in the prospects of the firms to which they provide resources. For example, providers of equity and debt will both value signals that reduce uncertainty about a firm's propensity to realize growth, or at least stability. Prospective employees, meanwhile, often seek prospects for stable employment or professional advancement (Aldrich and Ruef 2006, Cardon and Stevens 2004) as well as access to reputational and social capital that will "provide greater opportunities later in their careers should they leave” (Williamson et al. 2002, p. 90). At the same time, it is hard for prospective resource providers to directly assess new firms. By definition, new firms present resource providers with very little historical information upon which to make predictions about their prospects (Aldrich and Ruef 2006). As a result, resource providers seeking to evaluate new firms are likely to draw inferences about those firms' prospects based on their perceptions of the new firm's affiliates (Stuart et al. 1999, Stuart 2000). In particular, they are likely to look for information that enables them to formulate perceptions about the affiliate firm’s ability to create value (i.e., its reputation). 
A VC's ability to create value is a function of its abilities to select and coach new ventures (Sorensen 2007). ${ }^{2}$ VCs vary with regard to these abilities, but it is difficult for observers-even knowledgeable observers — to assess these skills directly (Kerr et al. 2014, Ragozzino and Reuer 2011). Many elements of the selection and coaching process occur in private, and those that are visible often entail subtle aspects of judgment and communication (Sapienza et al. 1996, Shepherd 1999). In addition, because venture investment outcomes are highly variable and hard to predict, it is difficult for observers to disentangle the roles that luck and skill play in shaping investment outcomes (Gompers et al. 2006). For these reasons, prospective resource providers are likely to look to characteristics of the VC affiliates that enable them to formulate perceptions of the affiliate's reputation.

\section{“Being Known” and "Being Known for Something” as Distinct Dimensions of Reputation}

In response to the need to consider how distinct dimensions of reputation operate in the process of reputation-borrowing, we focus on two of the three dimensions of reputation identified by Lange et al. (2011): “being known”, corresponding to the general awareness of a firm, and “being known for something”, corresponding to the assessment of a particular firm attribute. These two dimensions correspond closely to the two most commonly-studied dimensions of reputation identified in Barnett et al.'s (2006) review of the reputation literature and to the two key dimensions of reputation Rindova et al. (2005) identified. We considered also focusing on the third dimension identified by Lange et al. (2011), "generalized favorability”. However, we share Jensen et al.’s (2012) sense that “defining reputation as overall assessments ... is less useful when it comes to studying and managing reputation across different assessments and audiences” (p. 144-145). Given our intention to examine how reputation-borrowing affects young firms’ abilities to attract

\footnotetext{
${ }^{2}$ Selection skills are important, because venture investing is highly uncertain: Many new firms fail, and the quality of any given firm is often hard to assess. As a consequence, VCs are extremely selective in the firms they choose to support. In addition, VCs can influence the prospects of their portfolio firms through value-adding (or “coaching”) activities. For example, VCs may add value to their portfolio firms by influencing the structure and experience of the entrepreneurial team or by assisting in the formulation and implementation of strategies (Sapienza et al. 1996).
} 
specific types of resources, we focused on perceptions related to awareness and assessment rather than on generalized favorability. ${ }^{3}$

Given our interest in studying these distinct dimensions of reputation, we focused on two characteristics of VC affiliates: their media prominence and their industry-specific experience. We chose these two characteristics because both have been recognized in prior research as reputation-related informational signals (e.g., Dimov et al. 2007, Hsu 2004, Lee et al. 2011). Moreover, their simplicity (relative to, say, composite indices) enables us to focus more clearly, both theoretically and empirically, on how specific groups of people respond to specific signals. In addition, each of these characteristics is likely to influence a distinct dimension of reputation. ${ }^{4}$

Media prominence captures the extent to which a firm receives large-scale collective recognition within an organizational field. Media coverage is an important vehicle through which firms achieve largescale public recognition, because the media acts as a critical conduit of information in society, yet firms vary considerably in terms of the degree of coverage they receive (Deephouse 2000). More prominent VCs may receive more investment proposals and may generate more publicity for the firms they back, and these factors may enhance their selection and coaching capabilities, respectively (Stuart 2000). The media prominence of a VC affiliate is a characteristic that influences the dimension of reputation concerned with awareness, or "being known” (Rindova et al. 2005, Rindova and Martins 2012). In other words, when observers recognize that a VC possesses a high degree of media prominence, they are more likely to formulate the reputational perception that the VC firm is known.

\footnotetext{
${ }^{3}$ We also considered focusing on sociological concepts related to an affiliate's reputation, including its "legitimacy" and "status". However, we share Bitektine's (2011) sense that legitimacy and status capture observers' efforts to "answer different questions" with regard to a focal organization, whereas reputation captures the kind of judgment most germane to the resource-provision behaviors we seek to predict: namely, a judgment about how an organization "will perform/behave in the future relative to other organizations in the set" (p. 163). Observers seeking to make such judgments are likely to look to reputation, because, as Jensen and Roy (2008) observe, "reputation determines the selection the [observer] makes among the alternatives in the choice set” (p. 495).

${ }^{4}$ We acknowledge that other characteristics may also influence resource-provision decisions; however, not all such characteristics represent inputs to reputation. For example, an individual financier may favor (or disfavor) a given VC affiliate based on the location(s) of the firm's offices. But in the absence of a clear link between this characteristic and the perceived ability of the VC firm to create value, we would not regard this characteristic as an input to reputation. We also would not expect such preferences to exert a systematic influence on the behavior of an entire set of resource providers.
} 
Industry-specific experience captures the degree to which a VC has experience investing in the same industry as a particular portfolio firm. Industry-specific experience is relevant to the development of capabilities in many kinds of firms (including the selection and value-adding capabilities of VCs), because organizations are better able to assimilate and exploit knowledge when they have previously accumulated experience within related knowledge domains (Cohen and Levinthal 1990). Industry-specific experience is a characteristic that influences the dimension of reputation concerned with assessment, or "being known for something” (Rindova et al. 2005, Hsu 2004). In other words, when observers recognize that a VC possesses a high level of industry-specific experience, they are more likely to formulate the reputational perception that the VC firm is known for something.

In summary, past research suggests that a VC firm's media prominence and its industry-specific experience are both characteristics that are liable to influence observers' reputational perceptions—i.e., their perceptions about the VC firm's ability to select and coach new ventures. Thus, these characteristics convey reputation-related informational signals. However, existing theory tells us little about how the effectiveness of reputation-related signals might differ across different sets of resource providers. To aid us in answering that question, we turn to information processing theory.

\section{An Information Processing View of Reputation-Borrowing by New Firms}

Information processing theory seeks to explain differences in behavior as a function of differences in the way people acquire and interpret the information in their external environments (Galbraith 1973, Kotha and Swamidass 2000, Lord and Maher 1990). In this respect, information processing theory contrasts with some other theoretical perspectives that have been applied to the study of reputation, such as signaling theory, which tend to assume that reputation-related signals are transmitted to and interpreted by observers in a uniform, “objective” manner (Bergh et al. 2014, Carson et al. 2003). By instead breaking signal reception down into a set of constituent cognitive processes (including acquisition and interpretation), information processing theory allows for variations in how signals are received and thereby gives us a basis for predicting when and why some signals will be more effective than others (Bergh et al. 2014). Building on this theory, 
we propose that different sets of resource providers will respond to different characteristics of new firms' VC affiliates in formulating reputational perceptions about those affiliates and, by extension, drawing inferences about the new firms’ prospects.

One reason for this is that people may differ in the extent to which they acquire specific signals, owing to the fact that they occupy different “information environments” (Davenport 1997, Huber and Daft 1987). The concept of an information environment is based on the notion that when people gather information about their environments, they do not do so by attending to "the environment" directly or in its entirety but rather by attending to an "information environment", which is comprised of the set of information that is actually available, or "sensable", to those people about their environment (Huber and Daft 1987, p. 154). Building on this notion, scholars have shown that one can better understand how categories of people—such as stock analysts (Barron et al. 1998)—make decisions by paying careful attention to the information environments they occupy (Davenport 1997). In our context, this implies that different sets of resource providers may be more or less likely to acquire reputation-related signals based on differences in their information environments.

Another reason is that people may possess very different levels of experience relevant to interpreting signals (Lord and Maher 1990, Payne et al. 1993). In order for a person’s resource-provision behavior to be influenced by a signal after it is acquired, that person must interpret the signal by drawing reputation-related inferences from it. But the ability to draw inferences from any given signal is not guaranteed. Rather, it depends on whether the person possesses pre-existing knowledge structures that would enable him/her to do so (Heil and Robertson 1991), and the possession of those structures, in turn, is a function of experience (Lord and Maher 1990). Building on this notion, scholars have shown that professional and nonprofessional investors access and interpret firms' financial reports differently (Fredrickson and Miller 2004, Hodge and Pronk 2006). In our context, this implies that different sets of resource providers may be more or less able to interpret reputation-related signals based on differences in their knowledge and experience. 
In the sections that follow, we build on these general theoretical arguments to develop hypotheses about the extent to which prospective financiers and employees are likely to respond to specific characteristics of VC affiliates in deciding whether to provide resources to new firms. In keeping with past research, we propose that observers will be more likely to provide resources to new firms when they perceive that those firms have reputable affiliates. However, we further propose that some observers will be more likely than others to formulate the perception that a given affiliate is reputable. Recall, moreover, that each of the characteristics we include in our model corresponds to a distinct dimension of reputation within prevailing multi-dimensional frameworks of reputation (e.g., Lange et al. 2011): Media prominence corresponds to the dimension of reputation that captures "being known", whereas industry-specific experience corresponds to the dimension of reputation that captures "being known for something”. When observers are more (or less) able to recognize and interpret the signals conveyed by each of these characteristics, they will be more (or less) likely to formulate the corresponding reputational perception (i.e., that a VC firm is known or known for something). Figure 1 depicts the relationships we propose among affiliate characteristics, observers' reputation-related inferences and new firms' resource attraction outcomes.

\section{*** Insert Figure 1 about here ***}

\section{Research Hypotheses}

As we explained earlier, both the prominence and the industry-specific experience of a firm's VC affiliate may induce an observer to perceive that the affiliate is reputable. Accordingly, we expect that both of these characteristics will influence prospective resource providers' decisions. At the same time, we expect that these characteristics will be less influential in attracting prospective employees than in attracting prospective financiers. This is true because prospective financiers will be more likely than prospective employees to acquire and interpret the signals these characteristics convey and, by extension, to formulate the reputational perceptions that correspond to them. 
Prospective financiers will be more likely to acquire the signals, because they occupy an information environment in which those signals are more abundant and because they are more likely to have accumulated expertise relevant to interpreting the signals. For example, prospective financiers often work within organizations that have established specialized scanning routines and, accordingly, devote significant time and resources to gathering information related to alternative investment opportunities, including information about VC investments (Manigart and Witmeur 2009). Individually, too, prospective financiers will generally be engaged in careers that involve regular exposure to information about the identities and investment practices of various investors, including VCs (Wright and Lockett 2003). One way they are likely to encounter this information is by being embedded in professional networks that include representatives of VC firms and people knowledgeable about those firms (Sorenson and Stuart 2001). More generally, the career experiences of prospective financiers will leave them well acquainted with the context from which the signals derive their meaning, i.e., the VC investment process (Sapienza et al. 1996). As a consequence, prospective financiers will be well-equipped to translate these characteristics (i.e., prominence and industryspecific experience) into reputational perceptions.

Prospective employees, by contrast, are less likely to acquire and successfully interpret these signals. To the extent that firms need employees possessing various kinds of knowledge and skill, attracting employees often requires firms to solicit resources from a large and diverse group of individuals (Rynes and Barber 1990). As individuals, they will not have access to organizational-level scanning routines to help them acquire information about VC affiliates. In addition, these individuals possess a variety of educational levels and come from a wide variety of industry and organizational backgrounds. VC finance, meanwhile, represents a specialized industry domain, and knowledge about this domain is not universally distributed— rather, it represents a domain about which people possess varying degrees of expertise (e.g., Vanacker et al. 2014). Although some prospective employees may have prior experience interpreting VC affiliations in connection with decisions about where to seek employment, most prospective employees are unlikely to have done so repeatedly or, in any event, with a level of frequency that approaches the frequency with which financial professionals interpret signals based on VC affiliations. Thus, many prospective employees will 
lack the pre-existing knowledge structures needed to retrieve or process information about variations in VC characteristics (Hodge and Pronk 2006, Lord and Maher 1990). We do not contend that such knowledge structures will be entirely nonexistent among prospective employees, but we do maintain that-on average - they will be weaker and less extensive than those possessed by professional financiers. As a consequence, we expect that prospective employees will be less likely than prospective financiers to formulate reputational perceptions on the basis of VCs' characteristics.

Note that our arguments here represent a departure from some past work on the effects of media (e.g., Pollock and Rindova 2003) in that, consistent with our information processing perspective, we focus in detail on the process by which specific groups of people scan for and interpret environmental information (Daft and Weick 1984). As a result of this focus, we anticipate that people attending to the same form of media may exhibit differences in scanning within that form (e.g., searching for or noticing specific articles, such as those past the "front page” or those accompanied by major headlines). In addition, our approach implies that even people who consume the same piece of information (e.g., a reference to a VC within an article) may differ in their ability to interpret that piece of information.

In sum, we expect that prospective financiers, who occupy a richer information environment and have significant experience in evaluating firms, are more likely than prospective employees to acquire and interpret the signals conveyed by the characteristics of VC affiliates. As a consequence, prospective financiers are more likely than prospective employees to formulate reputational perceptions on the basis of those characteristics and, by extension, to draw inferences about new firms' prospects on the basis of those perceptions. Thus,

HYPOTHESIS 1. The media prominence of a VC-backed firm's lead investor will influence the firm's ability to attract financial resources more strongly than its ability to attract human resources.

HYPOTHESIS 2. The industry-specific experience of a VC-backed firm's lead investor will influence the firm's ability to attract financial resources more strongly than its ability to attract human resources. 
Although we expect that prospective financiers will respond to both the prominence and industryspecific experience of VC affiliates in deciding whether to provide financing to firms, we also expect that financiers will weight these reputation-related signals differently.

Media prominence represents a relatively general signal of a VC affiliate's reputation: High levels of prominence imply that a VC is "known" (Dimov et al. 2007). When financiers perceive that a VC is prominent, they may infer that it can select investments from a broader pool of proposals, thereby enhancing its ability to select more promising firms (Stuart 2000). Prospective financiers may also infer that VCs with higher levels of media prominence are likely to generate more publicity for the firms they back (thereby enhancing their coaching abilities) as well as more interest from buyers later in the process when they exit their investments (thereby generating higher valuations) (Cook et al. 2006). These inferences, while plausible and substantive, still provide relatively general indications of VC reputation.

On the other hand, high-levels of industry-specific experience provide a more specific indication of VC reputation - they indicate that a VC is "known for something”, specifically that the VC has accumulated knowledge relevant to the development of firms in a specific industry (Hsu 2004). Because VC investing is a complex, knowledge-intensive domain, the fact that a VC has accumulated such knowledge represents richer, more salient information about a VC’s ability to effectively select and coach a given firm. Knowing that a VC has industry-specific experience enables observers to formulate a reputational perception that reflects a more precise assessment of the VC firms' capabilities than would be possible based only on the knowledge that the VC is prominent. By extension, industry-specific experience provides a stronger basis than does media prominence for drawing inferences about the prospects of the firms backed by a VC. As we noted above, financiers may still value both general and specific reputation-related signals, given the inherent uncertainty of venture investing. But they are likely to pay more attention to industry-specific experience. Thus,

HYPOTHESIS 3. A VC-backed firm's ability to attract financial resources will depend more on the industry-specific experience of its lead investor than on the media prominence of that investor. 
We further expect that VC affiliates’ characteristics will be processed differently by prospective employees. As we have argued, prospective employees as a group are, on average, likely to have less intimate and less extensive experience with the VC investment process, and they occupy a more diffuse information environment. Therefore, their resource-provision decisions are likely to be more heavily influenced by the more general aspect of an affiliate's reputation, i.e., the degree to which the VC is known.

There are two reasons for this. First, firms backed by more prominent VCs are likely to generate awareness among a larger pool of prospective employees. Practically speaking this may occur when a firm is identified and described in a press release issued by a prominent VC. Awareness that a firm exists is an important prerequisite to an individual's decision to seek employment from that firm (Williamson 2000, Williamson et al. 2002). Affiliation with a prominent VC, therefore, represents a means by which new firms can enter into the "consideration set” of resource providers and thereby surmount a critical first hurdle in attracting human resources (Jensen and Roy 2008, Williamson 2000). It is likely to be harder for firms to surmount this hurdle in the minds of prospective employees than in the minds of prospective financiers, because in order to draw the attention of people monitoring a broad, diffuse information environment, firms must compete with a wider array of organizations and other stimuli.

Second, the media prominence of a VC affiliate is likely to be an easier signal to interpret than is industry-specific experience. To the extent that media prominence is a simple function of the volume of media coverage a firm receives, it is a signal that is more readily accessible to prospective employees occupying a broad information environment. Media prominence is likely to cause a firm to be evaluated more favorably, consistent with the well-documented "mere exposure" effect in psychological studies (Harrison 1977, Zajonc 1968). This effect refers to the tendency for repeated exposure to a stimulus (e.g., a firm's name) to result in subjects experiencing more positive affect towards the stimulus. Pollock and Rindova (2003) introduced this effect into the firm reputation literature, and there is evidence that the effect extends to prospective employees as well. For example, Gatewood et al. (1993) found that job-seekers had more favorable impressions of firms with which they were more familiar. Such findings imply that 
prospective employees may formulate and act on the reputational perception that a VC is known (based on the observation that it is prominent), even when they lack a detailed understanding of exactly what VCs do.

In some cases, new firms proactively reach out to recruit employees, thereby introducing themselves into a prospective employee's consideration set (Wasserman 2012). Even in these cases, however, new firms may still benefit from affiliation with prominent VCs, since successful recruitment requires that prospective employees view new firms as desirable or attractive employers (Williamson 2000, Williamson et al. 2002). In these cases, the mere exposure effect can lead prospective employees to formulate more favorable impressions of new firms that are funded by more prominent VCs. Alternatively, it may be easier for employees to find media coverage of a VC affiliate if they should seek it. In either event, new firms can benefit from a prospective employee's perception that a VC affiliate is known.

On the other hand, formulating the perception that a VC is known for something (based on the observation that it possesses industry-specific experience) requires a considerable degree of specialized knowledge. Specifically, observers must understand the overall value of industry-specific experience as well as the degree of industry-specific experience possessed by specific VCs. These elements of knowledge are not likely to be widely distributed among prospective employees (Manigart and Witmeur 2009). Consider, for example, that general management publications see fit to periodically publish articles that provide a very general introduction to VC for the "lay” reader (e.g., De Clercq et al. 2006). The appearance of such articles implies that most prospective employees of new firms do not possess such a detailed knowledge of the VC industry that they could be expected to know and compare the levels of industry-specific experience possessed by specific VCs. Accordingly, many prospective employees are unlikely to perceive that a VC is known for something on the basis of a VC's industry-specific experience. Rather, they are more likely to formulate and act on a reputational perception based on a VC's prominence-a more widely and more readily understood reputation-related signal. Thus,

HYPOTHESIS 4. A VC-backed firm's ability to attract human resources will depend more on the media prominence of its lead investor than on the industry-specific experience of that investor. 


\section{Research Design}

\section{Sample and Data Sources}

We investigate our research question using a sample of 94 Belgian firms that received VC investments. By focusing on the Belgian context we are able to take advantage of a database compiled by the Belgian Venture Capital \& Private Equity Association (BVA) — the leading professional association representing the Belgian VC community, which includes 36 VCs as full members. The BVA provided to us a random sample of onethird of the investments made by its members between 1999 and 2003. Our investigation is aided by an advantage of the Belgian setting, which is the availability of detailed data on private firms. Consequently, we are able to collect rich longitudinal data on each sample firm from the year when the investment was made up to five years after the initial VC investment, thereby capturing the typical life span of a VC investment. Our dataset includes 520 firm-year observations between 1999 and 2008.

We combine the BVA database with several other data sources. The Bel-first database is used to collect balance sheet, income statement and social balance sheet (reporting the number of employees and composition of the workforce) data for each sample firm. Reporting requirements imposed by the Belgian government require all limited liability firms —irrespective of their size and age—-to file detailed financial statements annually with the Belgian National Bank. Moreover, in the Belgian Law Gazette firms are required to publish an abstract of their foundation charter and to report subsequent capital increases and key changes in firm management, among other events. This information is externally validated by a notary. To collect entrepreneurial team data, we combine data from the Belgian Law Gazette with publicly available data from the Internet, press clippings and LinkedIn profiles of the team members. To collect data on the lead VC (as identified in the BVA database), we use comprehensive trade directories and Zephyr, a database of VC deals with a special focus on European deals. Finally, we collect data from Mediargus, a database of content from the most important Belgian newspapers.

The sample firms are, on average, 3.5 years old (median: 2) and have 9.5 employees (median: 4) when receiving their first VC investment. In addition, the median firm has 2 entrepreneurial team members, with no prior founding experience, before raising VC financing. Most firms are active in four sectors: 
computer and related activities (25\%), biotechnology (12\%), manufacturing (11\%) and wholesale (11\%). By the end of 2012, only 4 firms had conducted an initial public offering (IPO). ${ }^{5}$ In general, these firms are roughly similar in age to VC-backed firms in more developed entrepreneurial environments (e.g., Beckman et al. 2007, Hallen 2008, Hsu 2004), but they have fewer employees and fewer and less-experienced founders, and they are much less likely to experience an IPO.

\section{Definition and Measurement of Variables}

Dependent Variables. We use four dependent variables, which reflect the financial and human resources that VC-backed firms attract over time.

To capture the financial resources that VC-backed firms attract, we construct two measures. Our first dependent variable, total financial capital, is measured as the natural logarithm of the total amount of financing that VC-backed firms hold at various points in time (Cosh et al. 2009). This measure includes both equity and debt financing. VCs generally provide equity finance to their portfolio firms, and this is the case in Belgium as well (Manigart and Witmeur 2009). However, bank debt is a crucial source of financing for new firms, including VC-backed firms (Robb and Robinson 2014). We also constructed a second dependent variable, debt financing, which includes only debt and excludes subsequent equity investments. It is measured as the natural logarithm of the total amount of debt financing that VC-backed firms hold at various points in time. We did this for two reasons. First, VCs participating in the initial round may choose to invest equity in subsequent rounds as well, but the debt financing measure does not include such repeat investments. Second, because bank financing decisions are less likely than VC equity investment decisions to be influenced by the information flows that occur within VC networks, the debt financing measure enables us to mitigate the impact of such flows.

\footnotetext{
${ }^{5}$ The Belgian financial system is typical of a bank-based financial system in that IPOs are rare events. Even before the recent financial crisis, for instance, Belgium had only eight IPOs in 2005 and 14 in 2006. It is far more common for VCs in Continental Europe to exit through a trade sale-a practice which, in fact, is increasingly common in the U.S. as well (Gao, Ritter and Zhu 2013). However, because trade sales encompass widely-varying investment outcomes, they do not reliably indicate investment success.
} 
To capture the human resources that VC-backed firms attract, we also construct two measures. Total number of employees is measured as the natural logarithm of the total number of persons (on a full-time equivalent basis) that VC-backed firms employ at various points in time (Dencker et al. 2009). Attracting both skilled and unskilled employees is a key challenge for small new firms in Belgium, because prospective employees have a strong preference for large, mature corporations (Buyens et al. 2013). However, for certain jobs requiring skilled employees, including engineers, there is less than one candidate for each job opening (De Buck 2013). Thus, attracting skilled employees is especially challenging for new firms. To assess firms’ abilities to attract skilled employees, we take advantage of a distinction in employment contracts between employees that are primarily involved in manual labor and employees that are primarily involved in intellectual labor. ${ }^{6}$ There are significant differences between these two groups of employees in that employees in the latter category have, on average, higher education and earn higher wages. In addition, firing employees in the latter category is more costly for employers. Our final dependent variable, number of skilled employees, is measured as the natural logarithm of the number of employees that are primarily involved in intellectual labor and, accordingly, work under the more favorable employment contract.

Independent Variables. The key independent variables are the media prominence and industryspecific experience of the initial lead VC. We focus on the lead VC because this investor is likely to play the most important role in the initiation and governance of the investment (Wright and Lockett 2003). The lead VC is also listed first in press releases (Janney and Folta 2006). Moreover, VCs primarily syndicate first-round investments to other investors with similar levels of experience (Lerner 1994, Hallen 2008). Hence, the experience of the lead investor is likely to represent the average experience of the syndicate (Sorensen 2007). We focus on the initial lead investor, because it is difficult to separate the influence of first-round and later-round investors. For example, although later-round investors may themselves influence financial or human resource attraction, a firm's ability to attract such influential investors in later rounds also reflects the prior influence of the initial lead investor (Sorensen 2007).

\footnotetext{
${ }^{6}$ As of January 2014, several differences between the two types of employment contracts have been abolished (or reduced), and more uniform rules are now in place.
} 
VC media prominence is measured as the total number of media citations to the initial lead VC in Belgian national newspapers between 1995 and the year of investment. ${ }^{7}$ We use the Mediargus database to construct this measure. We focus on prominence because it captures the general level of awareness that is expected to matter most to prospective resource providers in our context (e.g., Dimov et al. 2007). We acknowledge that prominence and the tenor of media coverage (i.e., being "good" or "bad") represent distinct dimensions of media coverage (e.g., Pollock and Rindova 2003). However, because VCs are generally less controversial than other types of investors, such as buyout firms, tenor is a less salient dimension of media coverage in this context. ${ }^{8}$ Moreover, there is little variation in such a measure in our context. The number of citations to a VC ranges from zero to 654 . We use the natural logarithm of media citations plus a constant equal to 1 .

VC industry-specific experience is measured as the total number of investments made by the initial lead VC in the same industry (2-digit industry code) as the focal firm prior to the VC's investment in the focal firm (Hsu 2004). We use the 2-digit industry codes, because in practice VCs identify their own industry focus at this level. We triangulate multiple databases, including the BVA database, Zephyr database and industry directories, to reconstruct all prior investments made by the initial lead VC. Cumulative industry deal experience ranges from 1 to 26 investments with a median value of 2 investments. We use the natural logarithm of industry experience, because the value of each additional unit of experience is expected to be subject to decreasing returns.

Control Variables. Our analyses control for a broad set of firm characteristics, VC characteristics, industry effects and time effects.

\footnotetext{
${ }^{7}$ We counted the number of citations up to 1995 because a number of newspapers are no longer covered in the Mediargus database before 1995. In addition, we used alternative measurement windows for VC media prominence, based on the argument that prominence may have been more variable than we accounted for in our primary analyses. Specifically, we counted the number of citations of VCs in particular portfolio firms by using fixed five-year windows and fixed three-year windows. All these measures are highly correlated and provide similar results.

${ }^{8}$ To verify this inference, we looked carefully at a random sample of 50 articles and found that essentially all of the coverage VCs received in the Belgian press is descriptive and neutral in tenor (e.g., articles describe investments by VCs, fundraising activities by VCs, characteristics of the VC industry and VCs' opinions on industry matters). This finding is consistent with the observation of Dimov et al. (2007).
} 
In line with our econometric approach (see Eq. 1 below), we first add the lagged dependent variable to obtain growth models. In addition, to account for the possibility that the attraction of one type of resource subsequently affects attraction of the other, we include in each model lagged versions of the other dependent variable. Thus, in the models with total financial capital raised and debt financing raised we control for the lagged total number of employees attracted. And in the models with total number of employees and number of skilled employees, we control for the lagged total financial capital raised.

We include additional firm-level control variables. We control for firm age, measured as the difference between the year of the initial VC investment and the firm founding year, because firms of different ages tend to experience different growth patterns. In addition, prior work has found that entrepreneurial team (ET) members may influence subsequent resource attraction (e.g., Beckman et al. 2007). We therefore control for the number of ET members, calculated as the number of individuals who work for the firm in executive positions prior to VC financing. ${ }^{9}$ For each team member we determined whether that person had been a founder of other firms. Using that information, we constructed a dummy variable that was set to one if at least one ET member had prior founding experience before the firm raised VC financing, and to zero otherwise. The intangible assets ratio, or intangible assets divided by total assets, is used as a proxy to control for the firm's growth potential (Villalonga 2004). We also account for the possibility that firms develop their own reputations by demonstrating performance (Petkova 2012), for example by reaching key milestones or "proofpoints" such as generating initial sales or attracting many customers who purchase the product/service (e.g., Hallen and Eisenhardt 2012). We therefore construct a dummy variable, performance "proofpoint", which is equal to one when the value added realized by a firm increases by more than $25 \%$ (we also used the $10 \%$ and $5 \%$ threshold with qualitatively similar results).

\footnotetext{
${ }^{9}$ We focus on the composition of the ET before raising initial VC financing. Managers who join the team after the initial VC financing might also influence firm resource attraction. However, we know from prior research that the initial VC often plays an important role in further professionalizing the entrepreneurial team (Sapienza et al. 1996). Thus, the ability to attract such managers often reflects the influence of the initial lead investor.
} 
Value added is defined as sales minus the cost of inputs (or materials and services, but excluding labor expenses and other operational and financial expenses). ${ }^{10}$

We also control for VC characteristics. Larger VCs may have faster-growing firms in their portfolios for reasons unrelated to experience and prominence; for example, larger VCs may have more financial resources and other resources available to them. Thus, we control for $V C$ size, measured as the natural logarithm of the capital under management by the lead investor. Older VCs, meanwhile, may not only have more experience but may also have established a broader network in the VC community (Sorenson and Stuart 2001). Thus, we control for VC age, measured as the difference between the investment year and founding year of the lead VC. Some VCs are affiliated with other organizations, and these affiliations may shape the VCs' strategies and objectives, and, by extension, the growth patterns of their portfolio firms. For instance, bank-affiliated VCs may invest in firms for which they can then provide further financial services (Hellmann et al. 2008). We included two dummy variables indicating whether a firm received initial finance from government-related VCs or university-related VCs. Only one firm in the dataset received finance from a bank-related investor that acted as lead investor. No firms in our sample received financing from corporate investors. We control for the effect of syndication on resource acquisition in firms using a syndication variable, which measures the number of other VCs besides the lead VC that contributed initial financing to the portfolio firm. It is common for firms to receive finance from multiple investors (a syndicate) over several investment rounds (Lerner 1994).

To control for industry effects, we include industry dummies for the major industries represented within the study. As high-tech firms may exhibit different growth patterns from low-tech firms, we also construct a high-tech dummy variable, which equals one when a portfolio firm was active in a high-tech sector and zero otherwise. The classification of a sector as high-tech was based on a governmental

\footnotetext{
${ }^{10}$ We considered using sales growth as a "proofpoint", but we do not have consistent access to sales data on these firms. The small privately-held firms we study are required to report value added, but they are not obliged to report the two components that make up value added (i.e., sales and cost of inputs). However, an out of sample test using 9,800 observations from small firms that voluntarily reported sales indicates that sales and value added are highly correlated at 0.95 .
} 
classification scheme, which in turn was based on two-digit (and sometimes three-digit) industry codes. Based on this more detailed high-tech classification we are able to, for instance, differentiate between hightech and low-tech manufacturing. We also control for industry peer growth in total financing raised (for the models capturing growth in financial resources) and employees (for the models capturing growth in human resources). These variables capture the normal growth rates from firms in a particular industry with regard to each type of resource. Industry peers include all privately-held firms founded after 1995 and operating in the same three-digit industry as the focal firm. An industry's legitimacy may also influence a firm's resource attraction (e.g., Sine 2007). We therefore control for industry density or the natural logarithm of the number of firms that operate in the same three-digit industry as the focal firm. We further control for the average age of industry peers in the same three-digit industry as the focal firm.

Finally, given the time period of the initial investments (1999-2003), the sample includes investments that occurred during a period of considerable turbulence, especially in Internet-related businesses. To control for changes in the investment behavior of VCs, we include investment year dummies. Because we are modeling the year-by-year resources acquired by firms, we further include accounting year dummies to account for any general economic events or trends.

\section{Econometric Approach}

In line with prior research (Stuart 2000), we estimate the following growth equation:

$$
\ln \left(S_{i, t+1}\right)=\alpha \ln \left(S_{i t}\right)+\beta x_{i t}+\varepsilon_{i, t+1}(E q .1)
$$

where $\mathrm{S}$ is a time-varying measure of the financial resources (total financial capital and debt financing) or human resources (total number of employees and number of skilled employees) that VC-backed firms attract. An adjustment parameter $\alpha$ indicates how growth rates depend on the level of financial resources or human resources, respectively. Finally, $\beta$ represents a vector of parameters characterizing the effects of our independent and control variables.

The above equation models the ability of firms to attract additional financial capital, debt financing, employees and skilled employees over time. The ability of firms to raise financial and human resources both 
represent dimensions of firm growth. These dimensions may be correlated with one another, but they need not be: The same firm can exhibit distinct growth trajectories depending on which dimension of growth one attends to (Delmar et al. 2003). Therefore, the fact that a firm has grown on one dimension does not necessarily imply that it will exhibit similar growth on all other dimensions. This implies, moreover, that insights from studies on the mobilization of one particular type of resource will not necessarily generalize to other types of resources. This is important because it underscores the need for studies that, like this study, clarify how young firms attract different types of resources over time.

With a pooled dataset consisting of up to six years of data for each firm, we tested our hypotheses using generalized estimating equations (GEE), which accommodate the analysis of panel data with repeated, within-subject measures (e.g., Ballinger 2004). The GEE approach for modeling longitudinal data accounts for unobserved heterogeneity across firms and accounts for the lack of independence across observations for the same firm (Katila and Ahuja 2002). In GEE models, one must choose a distribution for the dependent variable, a link function to relate the outcome to the dependent variables, and a specification of the “working” within-firm correlation matrix (Ballinger 2004). We chose a normal distribution and an identity link function that corresponded to a linear model. For the correlation matrix, we used the "exchangeable" matrix option.

\section{Results}

\section{Main Results}

Table 1 reports means, standard deviations and correlations of all variables except industry, investment year and accounting year dummies used in the analysis. The correlation between VC media prominence and VC industry-specific experience is 0.58 , showing that although the measures are related, they are also distinct from each other. Variance inflation factors (VIFs) are well below the critical threshold of 10 (the maximum is 3.39) and hence do not indicate that multicollinearity may be unduly influencing our results. ${ }^{11}$

\footnotetext{
${ }^{11}$ We also created orthogonalized measures for VC media prominence and VC industry-specific experience (see, for instance, Pollock and Rindova (2003)). By doing so, we "partial out" the common variance, which implies the
} 


\section{***Insert Table 1 about here ${ }^{* * *}$}

Table 2 presents the results of our analysis. For each dependent variable, we first present models with only control variables. Model 1 reflects growth in the total amount of financial capital attracted over time, model 3 reflects growth in the amount of debt financing attracted over time, model 5 reflects growth in the total number of employees attracted over time and model 7 reflects growth in the amount of skilled employees attracted over time. To these baseline models, we add the independent variables in models 2, 4, 6 and 8 , respectively. ${ }^{12}$

The control variables provide some interesting insights. Consistent with prior research (e.g., Stuart 2000) the lagged dependent variables show that growth is size-dependent. Also, prior founding experience allows entrepreneurs to raise more debt financing, but other controls related to entrepreneurial team characteristics are not significant. Although this lack of significance may seem surprising, the fact that all firms in our sample have already raised VC minimizes the possibility that entrepreneurs are unable (or unwilling) to raise additional resources because they lacked "trivial” necessary conditions (Hallen and Eisenhardt 2012: 39), such as basic human capital and growth ambitions. Moreover, as we noted earlier, these firms and their founders differ in several ways from those found in highly developed entrepreneurial ecosystems, such as Silicon Valley. Nevertheless, firms that achieve "proofpoints", measured as sharp increases in value added, exhibit higher growth in total financial capital and total number of employees. Relatedly, firms that attracted more employees subsequently attract more financial resources.

***Insert Table 2 about here ${ }^{* * *}$

transformed measures will be uncorrelated with each other but are still correlated with the dependent variables. Results remain qualitatively similar.

${ }^{12}$ We included failed firms, or those firms that ceased to operate over the time frame of the study. Some $8.5 \%$ of firms in the sample failed during the first five years after receiving their first VC investment (Note that other firms turned out to be "living dead", i.e. firms which survived from a legal standpoint, but did not realize significant growth and, therefore, did not provide the VC with a significant return. Such investments represent failures from an investor's perspective). Eliminating the firms that failed from the analysis could potentially introduce survivorship bias. Following Eisenhardt and Schoonhoven (1990) we analyzed the data for failed firms in two ways: (1) including failed firms and assuming they did not acquire human and financial resources for each year in which they might have acquired such resources had they lived, and (2) excluding the failed firms altogether. The results we present below reflect the first approach, but both approaches provided qualitatively similar results. 
Hypothesis 1 stated that the media prominence of a firm's lead investor would more strongly influence a firm's ability to attract financial resources than its ability to attract human resources. We begin with simple qualitative comparisons of the coefficients and their significance. In models 2 and 4, which examine the attraction of financial resources, the coefficients for VC media prominence are not significantly different from zero. Hence, we fail to find evidence that firms backed by VCs with more media prominence exhibit higher growth in terms of the total amount of financial capital and debt financing they attract over time. Models 6 and 8 examine the attraction of human resources. In model 6, the coefficient for VC media prominence is positive and significant $(\beta=0.15$; $\mathrm{p}<0.05)$. Similarly, in model 8 , the coefficient for VC media prominence is positive and significant $(\beta=0.18 ; \mathrm{p}<0.10)$. When a VC's media prominence doubles, the total number of employees and number of skilled employees attracted by its portfolio firms increase annually by $11 \%$ and $13 \%$, respectively. However, while qualitative comparisons of the coefficients are instructive, they do not provide statistical evidence for our hypothesis. Using seemingly unrelated estimation, we test for differences in the size of the coefficients for the same variable across regression models (e.g., Wade et al. 2006). We do not find a difference in the effects of VC media prominence in the models predicting growth in financial resources and the models predicting growth in human resources (in all cases $\mathrm{p}>0.10$ ). We thus find no support for Hypothesis 1 .

Hypothesis 2 stated that the industry-specific experience of a firm's lead investor would more strongly influence a firm's ability to attract financial resources than its ability to attract human resources. Models 2 and 4 examine the attraction of financial resources. In model 2, the coefficient for VC industryspecific experience is positive and significant $(\beta=0.59 ; \mathrm{p}<0.01)$. In model 4 , the coefficient for VC industry-specific experience is positive and significant $(\beta=0.67 ; \mathrm{p}<0.05)$. When a VC's industry-specific experience doubles, the amount of financial capital and amount of debt financing attracted by its portfolio firms increase annually by 51\% and 59\%, respectively. Interestingly, in models 6 and 8 , which examine the attraction of human resources, the coefficients for VC industry-specific experience are not significantly different from zero. Hence, we fail to find evidence that firms backed by VCs with more industry-specific experience exhibit higher growth in terms of the total number of employees and the number of skilled 
employees they attract over time. Using seemingly unrelated estimation, our results show that the effects of VC industry-specific experience are significantly greater in the models predicting growth in financial resources as compared to all models predicting growth in human resources (in all cases $p<0.05$ ). We thus find support for Hypothesis 2.

Hypothesis 3 stated that a firm's ability to attract financial resources would depend more on the lead investor's industry-specific experience than on its media prominence. In model 2, which models growth in the total amount of financial capital raised, VC industry-specific experience is positive and significant ( $\beta$ $=0.59 ; \mathrm{p}<0.01$ ), while VC media prominence is not significant. In model 4, which models growth in the amount of debt financing raised, VC industry-specific experience is positive and significant $(\beta=0.67 ; \mathrm{p}<$ 0.05), while VC media prominence is not significantly different from zero. T-tests for differences indicate that the effect of VC industry-specific experience is significantly greater than the effect of VC media prominence in the models predicting growth in the total amount of financial capital raised $(\mathrm{p}<0.01)$ and amount of debt financing raised $(\mathrm{p}<0.10)$. We thus find support for Hypothesis 3.

Although we hypothesized that affiliations with VCs would be less important for prospective employees than for prospective investors, we still expected that VC affiliate characteristics could influence prospective employees. Hypothesis 4 stated that a firm's ability to attract human resources would depend more on the VC's media prominence than on its industry-specific experience. In model 6, which models growth in the total number of employees, VC industry-specific experience is not significantly different from zero, while VC media citations is positive and significant $(\beta=0.15 ; \mathrm{p}<0.05)$. Similarly, in model 8 , which models growth in the number of skilled employees, VC industry-specific experience is not significantly different from zero, while VC media citations is positive and significant $(\beta=0.18 ; \mathrm{p}<0.10)$. T-tests indicate that the effect of VC media prominence is significantly greater than the effect of VC industry-specific experience in the models predicting growth in the total number of employees $(\mathrm{p}<0.05)$ and number of skilled employees $(\mathrm{p}<0.10)$. We thus find support for Hypothesis 4.

\section{Alternative Explanations and Robustness Tests}


The mechanism behind our hypothesized effects is reputation-borrowing. In this section we consider several alternative explanations for the effects we observe.

One alternative explanation holds that resource providers arrive at their own independent assessments of new firms' prospects, for example by engaging in detailed due diligence in connection with specific firms. We acknowledge that some independent assessment occurs, but thorough due diligence is costly and time-consuming, and it is infeasible for any resource provider to thoroughly assess an entire set of alternative firms. Consequently, earlier stages of screening are often guided by heuristics and similar mechanisms of cognitive simplification so that the set of closely-considered opportunities can be reduced to a tractable number (e.g., Shepherd 1999, Turban and Cable 2003). In addition, even when prospective resource providers proceed with due diligence in connection with a new firm, the firm's prospects remain very difficult to predict (Kerr et al. 2014). For both reasons, prospective resource providers are likely to rely on reputation-related signals conveyed by the new firms’ initial VC affiliates.

In some cases, resource providers can reduce their uncertainty by looking to reputational signals conveyed by the firm itself, as opposed to those borrowed from its affiliates. As Petkova (2012) explains, this can occur when new firms have "built" reputations through their own actions or when new firms are “endowed” with reputations based on their founders’ backgrounds. However, the extent to which a new firm is able to generate reputational signals is likely to vary with the age and context of a firm. For example, reputation-building efforts generally involve attracting attention from information intermediaries, such as the media, and such efforts are likely to be more influential during later stages of firm development, such as during an initial public offering (e.g., Pollock and Rindova 2003). Very small, private firms, on the other hand, tend to have limited marketing budgets and are often "under the radar" of widespread media attention. ${ }^{13}$ Founder backgrounds, meanwhile, have been shown to exert a strong influence on resource providers in highly developed entrepreneurial environments, such as Silicon Valley, where it is common for

\footnotetext{
${ }^{13}$ This is especially true in moderately-developed entrepreneurial environments, such as Belgium, where new firms attract less media attention than they do in some parts of the U.S. For example, the median (average) firm in our sample has no (0.9) citations in the media in the years before the initial VC investment.
} 
founders to have had prior experience starting firms or working for prominent technology firms (e.g., Beckman et al. 2007) and where prospective financiers and employees are themselves likely to be unusually attentive and discriminating. But where such conditions do not prevail, founder-based signals are less likely to substitute for affiliation-based signals.

Relatedly, firms may generate their own reputational signals by achieving certain milestones or “proofpoints” that help substantiate their potential (Hallen and Eisenhardt 2012). Again, the exchange of milestone-related signals is likely to be especially salient in settings in which both the firms and the investors are relatively sophisticated. For example, Hallen and Eisenhardt observe that timing around proofpoints is "difficult” and that it is accompanied by another catalyzing strategy, which they term "casual dating” (p. 47). Such practices are likely to be more common among firms founded in entrepreneurial "hotbeds" like those they studied, many of which were led by entrepreneurs who had previously led other successful firms (p. 40), and less common in more moderately-developed markets like Belgium, where entrepreneurs often lack such experiences (e.g., Vanacker et al. 2014). Nevertheless, we made some effort to account for these effects by controlling for "proofpoints”, such as sharp increases in performance (performance "proofpoint”) and scale (e.g., by controlling for the lagged total number of employees attracted by firms in the models examining the attraction of financial resources). In sum, although it is possible for new firms to generate their own reputational signals, resource providers are nevertheless likely to be influenced by the reputational signals conveyed by the firms’ initial VC affiliates.

As an alternative to either the use of reputation-related signals or the direct evaluation of new firm prospects, observers could independently evaluate specific VCs based on first- or second-hand information obtained through other (non-signal) sources. This is especially plausible in the case of those follow-on financiers who are themselves VCs, since they may have gathered information about other VCs through their prior professional experiences or through communications within their professional networks. However, such non-signal sources of information are unlikely to wholly substitute for the use of reputationrelated signals for several reasons. First, as we explained earlier, VCs' selection and coaching capabilities are themselves difficult to assess directly. Second, non-signal informational sources may themselves be used 
to convey signal-based information-as would occur, for example, if professional acquaintances were to discuss a VC’s media prominence or its industry-specific experience. Supplementary tests show that, in general, the VCs in our sample do not have extensive prior experience with one another: the average number of unique VCs with which a VC in our sample has previously coinvested (i.e., VC centrality) is five, and the median number is two-numbers that represent small percentages of the BVA membership. This relatively low rate of prior coinvestment is not surprising for a relatively young, developing VC ecosystem. When we add VC centrality to the regression specification in Table 2 (not reported but available upon request), our results remain virtually identical. Thus, although resource providers undoubtedly utilize nonsignal sources of information such as networks, such sources are unlikely to wholly displace the use of reputation-related signals.

Finally, some previous studies have suggested that the "best" VCs may select the "best" firms, which in turn attract more resources (Sorensen 2007). ${ }^{14}$ We acknowledge this possibility as well. However, if selection effects were to drive our results, then one would expect to see a different set of findings from those we observe here. For example, our findings do not support the supposition that the firms backed by more prominent VCs or firms backed by VCs with more industry-specific experience simply “do better”. Rather, the results in Table 2 indicate that different aspects of a VC's reputation are more or less associated with the acquisition of different resources. ${ }^{15}$

Following the example of several prior scholars (Lerner 1999, Stuart et al. 1999, Stuart 2000), we further undertook an indirect test of the reputation-borrowing mechanism by conducting a sample split

\footnotetext{
${ }^{14}$ Note that most of these studies use data from US investors and US firms, which comprise one of the most highly developed VC markets worldwide. Evidence from the moderately-developed European VC market, on the other hand, suggests that in that context the "best" VCs do not necessarily match with the "best" firms (Croce et al. 2013).

${ }^{15}$ We also performed additional tests, such as including inverse Mills ratios, which control for the unobservable firm characteristics more experienced or more prominent VC investors may use when selecting firms. To construct these inverse Mills ratios, probit regressions were first used to predict the likelihood that firms receive finance from different types of investors (VCs with high versus low industry-specific experience, VCs with high versus low number of media citations; all median split). These probit specifications included similar variables as those reported by Hsu (2004). From these probit regressions inverse Mills ratios were calculated. Our results remained qualitative similar, however, when including the inverse Mills Ratios. We also compared differences in growth pre-investment to examine if "better" VCs select firms that exhibit higher growth pre-investment (Davila et al. 2003). However, we failed to find differences in growth pre-investment between firms backed by more experienced and prominent VCs relative to those firms backed by less experienced and prominent VCs.
} 
intended to test whether our findings differed across subsamples of firms characterized by different levels of uncertainty. Theoretically, the effects of reputation-borrowing are expected to be particularly significant when there is more uncertainty about a firm's prospects (Stuart 2000). Thus, uncertainty represents a precondition for the specific mechanism we have proposed to explain our hypothesized relationships between the characteristics of firms' VC affiliates and the resources they attract. All new venture investments are characterized by at least some degree of uncertainty (Kerr et al. 2014). However, because firm-specific uncertainty is higher for firms active in technology-based industries, such as biotech and ICT, and younger firms, we expect that it will be especially difficult for prospective resource providers to independently assess the prospects of firms in these contexts and that, accordingly, resource providers will rely more heavily on reputation-related VC signals in these contexts. We ran separate models for biotech and ICT firms (versus firms active in other industries) and younger firms (versus older firms), which enables us to undertake an indirect test of the reputation-borrowing mechanism.

\section{***Insert Table 3 about here***}

The models in Table 3 indicate that our results are stronger for firms characterized by higher-levels of firm-specific uncertainty (i.e., high-tech firms, such as biotech and ICT firms, and younger firms). This is consistent with our claim on behalf of reputation-borrowing as a mechanism. Specifically, for firms operating in biotech and ICT industries and also for younger firms - subsets within which one would expect it to be especially difficult for resource providers to independently assess a new firm's prospects—we find strong evidence that different dimensions of an affiliate's reputation differently influence resource acquisition from different groups of prospective resource providers. For firms operating in other industries and older firms, we find weaker evidence of relationships between affiliate reputation and resource attraction. Taken together, the specificity and contingency of our results serve to strengthen the explanations we have advanced relative to endogenous explanations (Lerner 1999, Stuart 2000).

In summary, we acknowledge that resource attraction is a complex process that may be influenced by a variety of mechanisms. However, there is a strong theoretical and empirical basis for the reputationborrowing mechanism we have hypothesized. Ultimately, our hypothesized effects do not depend on 
audiences relying exclusively on reputation-related signals to reduce their uncertainty with respect to the prospects of new firms. Rather, we contend that those signals play a non-trivial role in decisions about resource provision.

\section{Discussion}

It is well-known that new firms can attract resources more readily by affiliating with more established firms and thereby borrowing their reputations (e.g., Petkova 2012, Stuart et al. 1999). To date, however, research on reputation-borrowing has not accounted for two important considerations: 1) new firms must attract resources from different groups of resource providers and 2) reputation is multidimensional. Taken together, these considerations prompted us to ask: Do different groups of prospective resource providers respond differently to the reputation-related signals conveyed by an affiliate's characteristics? We proposed a theoretical answer to this question by drawing on the reputation literature and on information processing theory. In particular, we proposed that new firms' resource-attraction outcomes depend on the ability of specific resource providers to successfully acquire and interpret the reputation-related signals conveyed by distinct characteristics of the new firms' VC affiliates.

Our findings are largely consistent with this contention: a VC affiliate's industry-specific experience is more influential in attracting resources from prospective financiers (who generally occupy a rich task-related information environment and have more domain-specific knowledge) than from prospective employees (who occupy a more diffuse information environment and have less domain-specific knowledge). In addition, each group of resource providers is more strongly influenced by a different reputation-related signal: prospective employees are more influenced by the VC affiliate's media prominence (a widely-accessible signal indicating that a VC is "known”), whereas prospective financiers are more influenced by the VC affiliate’s industry-specific experience (a more specialized signal indicating that a VC is "known for something”).

Our findings advance the literature on reputation-borrowing in several ways. First, by examining two affiliate characteristics and explaining their influence on observers' reputation-related inferences, our 
study provides empirical evidence that the reputations new firms borrow from their affiliates encompass distinct dimensions and illustrates that these dimensions can simultaneously influence resource-attraction in new firms. In doing so, our study provides some much-needed empirical grounding for recent theoretical work on the multidimensionality of firm reputations (Jensen et al. 2012). Second, by showing that new firms' affiliations influence the attraction of both human and financial resources over time, we expand the range of resource-attraction outcomes generally considered in the reputation-borrowing literature, which has historically focused primarily on financial outcomes (e.g., Gulati and Higgins 2003, Petkova et al. 2013, Pollock and Rindova 2003). In addition, by documenting that different resource providers respond differently to the same reputation-related signal and explaining why this occurs, we offer a theoretical model of reputation-borrowing that accounts more fully for the sociocognitive processes by which new firms communicate with prospective resource providers (Martens et al. 2007, Navis and Glynn 2011). Taken together, these contributions enrich the reputation-borrowing literature by linking it more fully with the more complex and nuanced understanding of reputation that is emerging within contemporary reputation research (Jensen et al. 2012, Lange et al. 2011, Petkova 2012). For example, Hallen and Pahnke (2016) recently showed that entrepreneurs can sometimes misperceive the quality indicated by a VC firm's objective track record. Our study, like theirs, calls attention to ways in which reputation-borrowing hinges on the complex and imperfect process by which people access and interpret informational signals.

Although our primary contribution is to the literature on reputation-borrowing by new firms, our study also addresses a more general need in the reputation literature. As several scholars have noted, the study of reputation requires in-depth attention to the antecedents of firm reputation as well as to the dimensions themselves (Boyd et al. 2010, Fombrun 2012, Rindova et al. 2005). Although reputations reside in the minds of stakeholders, reputations are developed over time through a series of bi-directional interactions between firms and their stakeholders (Bergh et al. 2010, Lange et al. 2011). Thus, arriving at a clear understanding of how firm reputations develop requires careful consideration of some of the specific interactions that unfold between firms and the various stakeholder groups with which they interact (Love and Kraatz 2009). For example, it is generally recognized that a key part of reputation development involves 
the transmission of informational signals by the firm to one or more stakeholder groups, where the signals reflect actions (e.g., affiliations) or characteristics of the firm itself (Bergh et al. 2010, Love and Kraatz 2009, Rindova et al. 2005). But the details of this process remain poorly understood and merit further empirical exploration (Jensen et al. 2012, Love and Kraatz 2009).There is a particular need for empirical studies of reputation that "pay greater heed to the role of time” (Barnett and Pollock 2012) as well as studies that adopt more behaviorally plausible assumptions (e.g., Hallen and Pahnke 2016). By shedding light on how different groups of observers respond to specific informational signals over time, we provide evidence and arguments that are relevant not only to the study of reputation-borrowing but to the more general study of reputation as well. For example, our study suggests that firms may benefit from developing a more nuanced understanding of how specific audiences respond to the reputation-related signals conveyed by specific affiliate characteristics and by targeting their behaviors and communications accordingly.

Finally, we add to the literature on new venture development by showing that new firms' resource attraction trajectories are shaped by their investors in more complex ways than past research has accounted for. It is widely recognized that VC investments enhance new firms’ development prospects (e.g., Sapienza et al. 1996). However, this recognition has yet to be clearly linked with the emerging recognition that "new venture growth” is itself a multidimensional phenomenon—that, as Delmar et al. (2003) observed: “all highgrowth firms do not grow in the same way” (p. 190). Underscoring this point, Ambos and Birkinshaw (2010) recently observed, "the literature offers surprisingly little insight into the detailed process—-the dynamics of constituent elements and the sequences of events-through which new ventures evolve” (p. 1125). Thus, there is a need for studies that explain more clearly how specific determinants of new firm growth lead to specific trajectories of resource attraction (Gilbert et al. 2006). Our study does this by showing that the reputation of a new firm's lead investor has different implications for the firm's ability to attract financial resources as opposed to human resources. In doing so, we help specify a critical early-stage link in the ongoing interaction between a firm's affiliations and the development of its resource base (Hite and Hesterly 2001, Khaire 2010). In addition, our longitudinal analyses of early-stage firm growth provide unusually rich empirical evidence of the various resource-attraction trajectories along which new firms can evolve. 
At the same time, we acknowledge that our study has limitations. Although we have provided theory and evidence consistent with the argument that differences in the behavior of different groups of resource providers are a function of differences in their information environments, we acknowledge that we do not directly examine differences in the information environments between and within these groups. Future research may attempt to more directly relate differences in the information environment between and within groups of resource providers to the theorized mechanisms of reputation-borrowing by new firms. Moreover, given that resource attraction is a complex process, other mechanisms (as we noted earlier) may operate in tandem with the reputation-borrowing mechanism that we focus on. We have taken steps to mitigate the concern that such alternative mechanisms are driving our results, but we acknowledge that we cannot address such issues conclusively. Finally, we focused on ventures in a single country, Belgium. The Belgian setting provided us with some significant empirical advantages, and we believe it is relevant to understanding other moderately-developed entrepreneurial environments. However, there is a need for future work to explore these questions in other geographic contexts as well.

Our findings should prompt scholars to pay more explicit theoretical attention to the processes by which resource providers receive and interpret reputation-related signals. By contrast, past research in this area has focused on the transmission of such signals (e.g., Jensen and Roy 2008, Sanders and Boivie 2004). The general idea that signal reception is theoretically complex was introduced into the strategy literature nearly two decades ago (Heil and Robertson 1991) and has been periodically invoked in more recent work (e.g., Kirsch et al. 2009). However, this notion remains significantly underappreciated and understudied in the organizational literature. Future scholars should draw further on information processing theory, as we have here, or on the idea of bounded rationality (e.g., Hallen and Pahnke 2016) to better understand when and why certain signals influence certain receivers more than do others.

For example, we focused in this study on two sets of signal receivers: financiers and employees. Although both of these are critical to the growth of young firms, they are not the only stakeholders relevant to new firms. Prospective customers and suppliers represent other sets of actors from whom new ventures need to attract resources and whose decisions may be influenced by reputation-borrowing affiliations (Long 
et al. 1993). Future research could explore the extent to which resource attraction from each of these groups is influenced by the degree to which a VC is known and known for something. From an information processing perspective, one would expect this to depend on the receivers' domain-relevant expertise and the information environments they occupy. On those dimensions customers and suppliers are likely to represent a relatively diffuse group of resource providers, and in that respect they may process reputation-related signals in a manner similar to employees (i.e., relying more on the prominence of new firms' affiliates). On the other hand, some customers and suppliers (e.g., those in industries where venture investment is more common) may occupy information environments that enable them to recognize and interpret the reputational signals conveyed by a VC affiliate’s industry-specific experience. Moreover, unlike prospective employees, customers and suppliers can both make smaller and more gradual resource commitments to new firms, and these considerations may also influence their resource-provision decisions. Overall, examining the impact of multidimensional reputation-borrowing for other groups of stakeholders is a promising avenue for future research. Relatedly, scholars should explore how firms manage the tradeoffs associated with the fact that a given act of affiliation may send multiple signals to multiple receivers.

At the same time, our study also indicated that reputational signals do not always operate differently across receivers. Specifically, we did not find support for the claim we made in Hypothesis 1: that media prominence would exert a significantly different influence on financial resources relative to human resources. Thus, it may be that, contrary to our arguments, media influences are generally consistent across audiences. However, the lack of support for this hypothesis may also be a function of the fact that, consistent with our interest in the degree to which an affiliate is "known”, we examined a relatively general dimension of media coverage (i.e., prominence). Differences in media influence might in fact be evident if future studies were to consider other, more fine-grained measures of media coverage, such as those that distinguish between general and specialized sources of media (e.g., Petkova et al. 2013). In addition, other sets of resource providers might exhibit greater differences in the extent to which they acquire and interpret mediarelated signals. 
Future research might also seek to better understand specific groups of resource providers, such as employees, whose resource-provision decisions are far less well researched than those of financiers. In doing so, scholars could build on existing research in organizational psychology, which has explored related issues, such as the extent to which people's propensity to seek employment at a particular firm are shaped by their familiarity with the firm and their impressions of its reputation (e.g., Turban and Cable 2003). Extensions of this work could help to clarify more fully when and how prospective employees' beliefs and behaviors are influenced by a firm's affiliations as well as which specific sources of information transmit the relevant reputation-related signals most effectively. Relatedly, given that prior research has argued that people at different levels within an organization are subject to different information environments (Gavetti 2005), future work could explore differences among specific subsets of employees (e.g., managers vs. scientists or salespeople vs. engineers) in terms of their ability to recognize and interpret the reputational signals conveyed by key affiliates' characteristics. ${ }^{16}$ We suspect that such contributions would be illuminating not only within the study of management but also in the broader literatures on labor economics and human resources, where the behavior of prospective employees remains empirically underexplored (Benson et al. 2015).

Finally, our study focused on new firms' affiliations with VC investors. In this context, prospective investors are likely to be in an information environment that makes them more likely to acquire and interpret the reputational signals conveyed by the characteristics of a $V C$ affiliate, relative to prospective employees. However, VC investors may not always be better able to acquire and interpret the reputational signals conveyed by a firm's affiliates. As new firms form R\&D alliances or affiliate with research institutes, for example, investors may actually possess less expertise relevant to interpreting the signals conveyed by such affiliations relative to some technically competent employees.

In conclusion, our study provides a more nuanced account of the process by which new firms borrow the reputations of their affiliates and its consequences for resource attraction. In particular, we show that for

\footnotetext{
${ }^{16}$ We are grateful to an anonymous reviewer for this suggestion.
} 
affiliations to be effective in facilitating new firms' resource attraction efforts, stakeholders need to recognize and interpret distinct reputation-related characteristics of new firms' affiliates. Thus, our study advances extant reputation research while helping to link research in that vein with information processing theory and the new venture development literature.

\section{References}

Aldrich H, Ruef M (2006) Organizations evolving, 2nd ed. (Sage, London).

Ambos TC, Birkinshaw J (2010) How do new ventures evolve? An inductive study of archetype changes in science-based ventures. Organ. Sci. 21(6):1125-1140.

Ballinger GA (2004) Using generalized estimating equations for longitudinal data analysis. Organ. Res. Methods 7(2):127-150.

Barnett ML, Pollock TG (2012) Charting the landscape of corporate reputation research. Barnett ML, Pollock TG, eds. The Oxford Handbook of Corporate Reputation (Oxford University Press, Oxford), 1-15.

Barnett ML, Jermier JM, Lafferty BA (2006) Corporate reputation: The definitional landscape. Corporate Reputation Rev. 9(1):26-38.

Baron JN, Hannan MT, Burton MD (2001) Labor pains: Change in organizational models and employee turnover in young, high-tech firms. Amer. J. Sociol. 106(4):960-1012.

Barron OE, Kim O, Lim SC, Stevens DE (1998) Using analysts' forecasts to measure properties of analysts' information environment. Accounting Rev. 73(4):421-433.

Beckman CM, Burton MD, O’Reilly C (2007) Early teams: The impact of team demography on VC financing and going public. J. Bus. Venturing 22(2):147-173.

Benson A, Sojourner AJ, Umyarof A (2015) Can reputation discipline the gig economy? Experimental evidence from an online labor market. IZA Discussion Papers, No. 9501.

Bergh DD, Connelly BL, Ketchen DJ, Shannon LM (2014) Signalling theory and equilibrium in strategic management research: An assessment and a research agenda. J. Management Stud. 51(8):1334-1360.

Bergh DD, Ketchen DJ, Boyd BK, Bergh J (2010) New frontiers of the reputation-performance relationship: Insights from multiple theories. J. Management 36(3):620-632.

Bitektine A (2011) Toward a theory of social judgments of organizations: The case of legitimacy, reputation, and status. Acad. Management Rev. 36(1):151-179.

Boyd BK, Bergh DD, Ketchen DJ (2010) Reconsidering the reputation-performance relationship: A resource-based view. J. Management, 36(3):588-609.

Buyens D, De Schamphelaere V, Verbrigghe J, Verhaeghe S (2013) It remains quite a challenge to fill vacancies. Available at: http://www.vlerick.com/en/research-and-faculty/knowledge-items/knowledge/itremains-quite-a-challenge-to-fill-vacancies 
Cardon MS, Stevens CE (2004) Managing human resources in small organizations: What do we know? Hum. Resour. Manage. Rev. 14(3):295-323.

Carson SJ, Madhok A, Varman R, John G (2003) Information processing moderators of the effectiveness of trust-based governance in interfirm R\&D collaboration. Organ. Sci. 14(1):45-56.

Cohen WM, Levinthal DA (1990) Absorptive capacity: A new perspective on learning and innovation. Admin. Sci. Quart. 35(1):128-152.

Cook DO, Kieschnick R, Van Ness RA (2006) On the marketing of IPOs. J. Financ. Econ. 82(1):35-61.

Cooper AC, Gimeno FJ, Woo CY (1994) Initial human and financial capital as predictors of new venture performance. J. Bus. Venturing 9(5):371-395

Cosh A, Cumming D, Hughes A (2009) Outside entrepreneurial capital. Econ. J. 119(540): 1494-1533.

Croce A, Martí J, Murtinu S (2013) The impact of venture capital on the productivity growth of European entrepreneurial firms. J. Bus. Venturing 28(4):489-510.

Daft RL, Weick KE (1984) Toward a model of organizations as interpretation systems. Acad. Management Rev. 9(2):284-295.

Dahl D (2012) A sea of job-seekers, but some companies aren't getting any bites. The New York Times, June 27.

Davenport T (1997) Information ecology: Mastering the information and knowledge environment (Oxford University Press, Oxford).

Davila A, Foster G, Gupta M (2003) Venture capital financing and the growth of startup firms. J. Bus. Venturing 18(6):689-708.

De Buck G (2013) International recruitment - a creative melting pot: Enhancing competition and innovation. European Employment Services (EURES).

De Clercq D, Fried VH, Lehtonen O, Sapienza HJ (2006) An entrepreneur's guide to the venture capital galaxy. Acad. Manag. Perspect. 20(3): 90-112.

Deephouse DL (2000) Media reputation as a strategic resource: An integration of mass communication and resource-based theories. J. Management 26(6):1091-1112.

Delmar F, Davidsson P, Gartner WB (2003) Arriving at the high-growth firm. J. Bus. Venturing 18(2):189216.

Dencker JC, Gruber M, Shah SK (2009) Individual and opportunity factors influencing job creation in new firms. Acad. Management J. 52(6):1125-1147.

Dimov D, Shepherd DA, Sutcliffe KM (2007) Requisite expertise, firm reputation, and status in venture capital investment allocation decisions. J. Bus. Venturing 22(4):481-502.

ECB (2009) Survey on the access to finance of small and medium-sized enterprises in the Euro area. Available at: http://www.ecb.europa.eu/stats/money/surveys/sme/html/index.en.html

Eisenhardt KM, Schoonhoven CB (1990) Organizational growth: Linking founding team, strategy, environment, and growth among US semiconductor ventures, 1978-1988. Admin. Sci. Quart. 35(3):504529. 
Flamholtz E, Randle Y (2007) Growing pains: Transitioning from an entrepreneurship to a professionally managed firm (Jossey-Bass, San Francisco, CA).

Fombrun CI (2012). Corporate reputation: Definitions, antecedents and consequences. Barnett ML, Pollock TG, eds. The Oxford Handbook of Corporate Reputation (Oxford University Press, Oxford), 94-113.

Fredrickson J, Miller J (2004) The effects of pro forma earnings disclosures on analysts' and nonprofessional investors’ equity valuation judgments. Accounting Rev. 79(3):667-686.

Galbraith JR (1973) Designing complex organizations (Addison-Wesley, Reading, MA).

Gao X, Ritter JR, Zhu Z (2013) Where have all the IPOs gone? J. Financ. Quant. Anal. 48(6):1663-1692.

Gatewood RD, Gowan MA, Lautenschlager GJ (1993) Corporate image, recruitment image and initial job choice decisions. Acad. Management J. 36(2):414-427.

Gavetti G (2005) Cognition and hierarchy: Rethinking the microfoundations of capabilities' development. Organ. Sci. 16(6): 599-617.

Gilbert BA, McDougall PP, Audretsch DB (2006) New venture growth: A review and extension. $J$. Management 32(6):926-950.

Gompers P, Kovner A, Lerner J, Scharfstein D (2006) Skill vs. luck in entrepreneurship and venture capital: Evidence from serial entrepreneurs. NBER paper (No. w12592).

Gompers PA (1995) Optimal investment, monitoring, and the staging of venture capital. J. Finance 50(5):1461-1489.

Gulati R, Higgins MC (2003) Which ties matter when? The contingent effects of interorganizational partnerships on IPO success. Strategic Management J. 24(2):127-144.

Hallen BL, Pahnke EC (2016) When do entrepreneurs accurately evaluate venture capital firms' track records? A bounded rationality perspective. Acad. Management J., In Press.

Hallen BL, Eisenhardt KM (2012) Catalyzing strategies and efficient tie formation: How entrepreneurial firms obtain investment ties. Acad. Management J. 55(1):35-70.

Hallen BL (2008). The causes and consequences of the initial network positions of new organizations: From whom do entrepreneurs receive investments? Admin. Sci. Quart. 53(4):685-718.

Harrison AA (1977). Mere exposure. In L. Berkowitz (Ed.), Advances in Experimental Social Psychology, 10: 39-83. Greenwich, CT: JAI Press.

Heil O, Robertson TS (1991) Toward a theory of competitive market signaling: A research agenda. Strategic Management J. 12(6):403-418.

Hellmann T, Lindsey L, Puri M (2008) Building relationships early: Banks in venture capital. Rev. Financ. Stud. 21(2):513-541.

Hite J, Hesterly W (2001) The evolution of firm networks: From emergence to the early growth of the firm. Strategic Management J. 22(3):275-286.

Hodge F, Pronk M (2006) The impact of expertise and investment familiarity on investors' use of online financial report information. Journal of Accounting, Auditing \& Finance 21(3):267-292.

Hsu DH (2004) What do entrepreneurs pay for venture capital affiliation? J. Finance 59(4):1805-1844. 
Huber GP, Daft RL (1987) The information environments of organizations. Jablin F, Putnam L, Roberts K and Porter L, eds. Handbook of Organization Communication. (Sage, Beverly Hills, CA), 130-163.

Janney JJ, Folta TB (2006) Moderating effects of investor experience on the signaling value of private equity placements. J. Bus. Venturing 21(1):27-44.

Jensen M, Kim H, Kim BK (2012) Meeting expectations: A role-theoretic perspective on reputation. Barnett ML, Pollock TG, eds. The Oxford Handbook of Corporate Reputation (Oxford University Press, Oxford), 140-159.

Jensen M, Roy A (2008) Staging exchange partner choices: When do status and reputation matter? Acad. Management J. 51(3):495-516.

Katila R, Ahuja G (2002) Something old, something new: A longitudinal study of search behavior and new product introduction. Acad. Management J. 45(6):1183-1194.

Kerr WR, Nanda R, Rhodes-Kropf M (2014) Entrepreneurship as experimentation. J. Econ. Perspect. 28(3):25-48.

Khaire M (2010) Young and no money? Never mind: The material impact of social resources on new venture growth. Organ. Sci. 21(1):168-185.

Kirsch D, Goldfarb B, Gera A (2009) Form or substance: The role of business plans in venture capital decision making. Strategic Management J. 30(5):487-515.

Kotha S, Swamidass PM (2000) Strategy, advanced manufacturing technology and performance: Empirical evidence from US manufacturing firms. J. Oper. Manag. 18(3):257-277.

Lange D, Lee PM, Dai Y (2011) Organizational reputation: A review. J. Management 37(1):153-184.

Lee PM, Pollock TG, Jin K (2011) The contingent value of venture capitalist reputation. Strategic Organ. 9(1):33-69.

Lerner J (1999) The government as venture capitalist: The long-run impact of the SBIR program. J. Bus. 72:285-318.

Lerner J (1994) The syndication of venture capital investments. Financ. Manage. 23(3):16-27.

Long MS, Malitz IB, Ravid SA (1993) Trade credit, quality guarantees, and product marketability. Financ. Manage. 22(4):117-127.

Lord R, Maher K (1990) Alternative information-processing models and their implications for theory, research and practice. Acad. Management Rev. 15(1):9-28.

Love EG, Kraatz M (2009) Character, conformity, or the bottom line? How and why downsizing affected corporate reputation. Acad. Management J. 52(2):314-335.

Manigart S, Witmeur O (2009) Venture capital guide for Belgium (BVA, Brussels).

Martens M, Jennings J, Jennings PD (2007) Do the stories they tell get them the money they need? Acad. Management J. 50(5):1107-1132.

Martins LL (2005) A model of the effects of reputational rankings on organizational change. Organ. Sci., 16(6):701-720. 
Navis C, Glynn MA (2011) Legitimate distinctiveness and the entrepreneurial identity: Influence on investor judgments of new venture plausibility. Acad. Management Rev. 36(3):479-499.

OECD (2013) Education at a glance 2013: OECD Indicators (OECD Publishing, Paris).

Payne J, Bettman J, Johnson E (1993) The adaptive decision maker (Cambridge University Press, Cambridge).

Petkova A, Rindova V, Gupta A. (2013) No news is bad news: Sensegiving activities, media attention, and venture capital funding of new technology organizations. Organ. Sci. 24(3):865-888.

Petkova AP (2012) From the ground up: Building young firms’ reputations. Barnett ML, Pollock TG, eds. The Oxford Handbook of Corporate Reputation (Oxford University Press, Oxford), 383-401.

Pollock TG, Rindova VP (2003) Media legitimation effects in the market for Initial Public Offerings. Acad. Management J. 46(5):631-642.

Ragozzino R, Reuer JJ (2011) Geographic distance and corporate acquisitions: Signals from IPO firms. Strategic Management J. 32(8):876-894.

Rao H (1994) The social construction of reputation: Certification contests, legitimation, and the survival of organizations in the American automobile industry:1895-1912. Strategic Management J. 15(S1):29-44.

Reuer JJ, Tong TW, Wu CW (2012) A signaling theory of acquisition premiums: Evidence from IPO targets. Acad. Management J. 55(3):667-683.

Rhee M, Valdez ME (2009) Contextual factors surrounding reputation damage with potential implications for reputation repair. Acad. Management Rev. 34(1):146-168.

Rhee M, Haunschild PR (2006) The liability of good reputation: A study of product recalls in the US automobile industry. Organ. Sci. 17(1):101-117.

Rindova VP, Martins LL (2012) Show me the money: A multidimensional perspective on reputation as an intangible asset. Barnett ML, Pollock TG, eds. The Oxford Handbook of Corporate Reputation (Oxford University Press, Oxford), 16-33.

Rindova VP, Williamson IO, Petkova AP, Sever JM (2005) Being good or being known: An empirical examination of the dimensions, antecedents, and consequences of organizational reputation. Acad. Management J. 48(6):1033-1049.

Rindova VP, Fombrun CJ (1999) Constructing competitive advantage: The role of firm-constituent interactions. Strategic Management J. 20(8):691-710.

Robb AM, Robinson DT (2014) The capital structure decisions of new firms. Rev. Financ. Stud. 27(1):153179.

Rynes SL, Barber AE (1990) Applicant attraction strategies: An organizational perspective. Acad. Management Rev. 15(2):286-310.

Sanders GWM, Boivie S (2004) Sorting things out: Valuation of new firms in uncertain markets. Strategic Management J. 25:167-186.

Sapienza HJ, Manigart S, Vermeir W (1996) Venture capitalist governance and value added in four countries. J. Bus. Venturing 11(6):439-469. 
Shane S, Cable D (2002) Network ties, reputation, and the financing of new ventures. Management Sci. 48(3):364-381.

Shepherd DA (1999) Venture capitalists' assessment of new venture survival. Management Sci. 45(5):621632.

Sine WD, David RJ, Mitsuhashi H (2007) From plan to plant: Effects of certification on operational startup in the emergent independent power sector. Organ. Sci. 18(4):578-594.

Sorensen M (2007) How smart is smart money? A two-sided matching model of venture capital. J. Finance 62(6): 2725-2762.

Sorenson O, Stuart TE (2001) Syndication networks and the spatial distribution of venture capital investments. Amer. J. Sociol. 106(6):1546-1588.

Stinchcombe A (1965) Social structure and organizations. March J., ed. Handbook of Organizations (Rand McNally, Chicago), 260-290.

Stuart TE (2000) Interorganizational alliances and the performance of firms: A study of growth and innovation rates in a high-technology industry. Strategic Management J. 21(8):791-811.

Stuart TE, Hoang H, Hybels RC (1999) Interorganizational endorsements and the performance of entrepreneurial ventures. Admin. Sci. Quart. 44(2):315-349.

Turban DB, Cable DM (2003) Firm reputation and applicant pool characteristics. J. Organ. Behav. 24(6):733-751.

Vanacker T, Manigart S, Meuleman M (2014) Path-dependent evolution versus intentional management of investment ties in science-based entrepreneurial firms. Entrep. Theory Pract. 38(3):671-690.

Villalonga B (2004) Intangible resources, Tobin's q and sustainability of performance differences. J. Econ. Behav. Organ. 54(2):205-230.

Wade JB, O’Reilly CA, Pollock TG (2006) Overpaid CEOs and underpaid managers: Fairness and executive compensation. Organ. Sci. 17(5):527-544.

Wasserman, N. 2012. The founder's dilemmas: Anticipating and avoiding the pitfalls that can sink a startup. Princeton, NJ: Princeton U. Press.

Williamson IO, Cable DM, Aldrich H (2002) Smaller but not necessarily weaker: How small businesses can overcome barriers to recruitment. Katz J, Welbourne T, eds. Advances in Entrepreneurship, Firm Emergence, and Firm Growth, Vol. 5 (JAI Press, Greenwich, CT), 83-106.

Williamson IO (2000) Employer legitimacy and recruitment success in small businesses. Entrep. Theory Pract 25(1):27-42.

Wilson R (1985) Reputations in games and markets. Roth AE, ed. Game-theoretic Models of Bargaining (Cambridge University Press, Cambridge), 27-62.

Wright M, Lockett A (2003) The structure and management of alliances: Syndication in the venture capital industry. J. Management Stud. 40(8):2073-2102.

Zajonc RB (1968) The attitudinal effects of mere exposure. J. Pers. Soc. Psychol. Monograph Supplement, 9: 1-27. 
Figure 1: Conceptual model and hypotheses

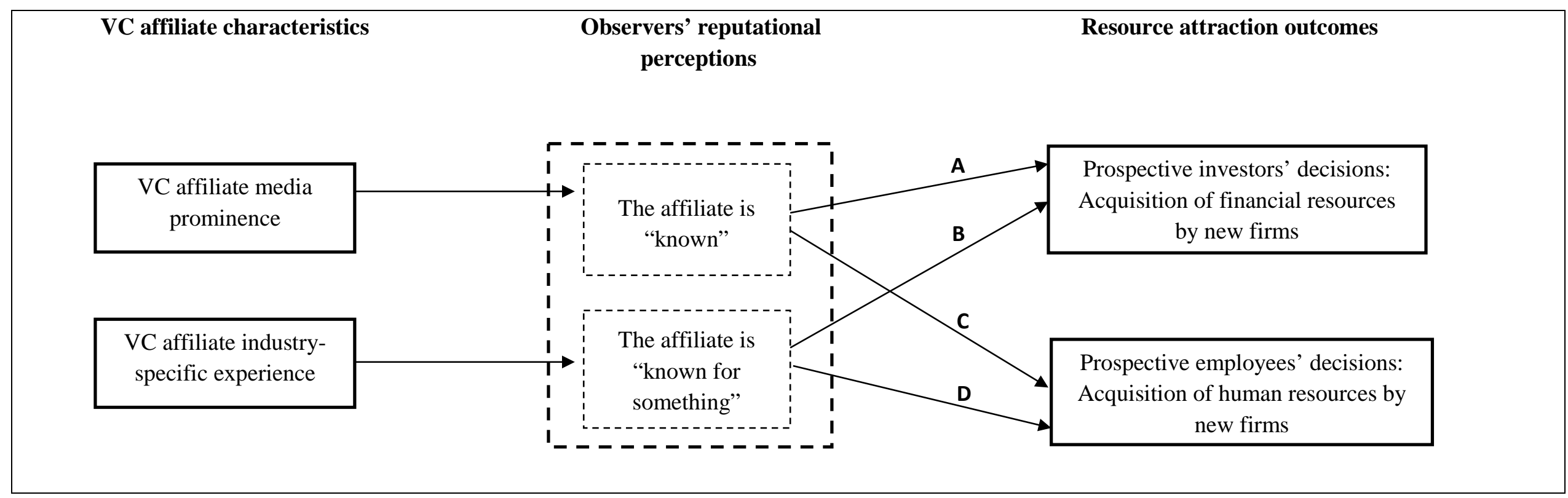

Hypothesis 1: A > C

Hypothesis 2: $\mathrm{B}>\mathrm{D}$

Hypothesis 3: B > A

Hypothesis 4: C > D 
Table 1: Means, standard deviations and correlations

\begin{tabular}{|c|c|c|c|c|c|c|c|c|c|c|c|c|c|c|c|c|c|c|c|c|c|c|}
\hline Variable & Mean & S.D. & 1 & 2 & 3 & 4 & 5 & 6 & 7 & 8 & 9 & 10 & 11 & 12 & 13 & 14 & 15 & 16 & 17 & 18 & 19 & 20 \\
\hline 1 Total financial capital $^{\mathrm{a}}$ & 7.23 & 1.99 & 1.00 & & & & & & & & & & & & & & & & & & & \\
\hline 2 Debt financing ${ }^{a}$ & 3.53 & 3.26 & 0.43 & 1.00 & & & & & & & & & & & & & & & & & & \\
\hline 3 Total \# of employees ${ }^{a}$ & 2.07 & 1.21 & 0.47 & 0.33 & 1.00 & & & & & & & & & & & & & & & & & \\
\hline 4 \# of skilled employees ${ }^{\text {a }}$ & 1.84 & 1.22 & 0.42 & 0.21 & 0.85 & 1.00 & & & & & & & & & & & & & & & & \\
\hline 5 VC media prominence ${ }^{a}$ & 1.00 & 0.54 & 0.23 & 0.12 & 0.31 & 0.29 & 1.00 & & & & & & & & & & & & & & & \\
\hline $6 \mathrm{VC}$ industry experience ${ }^{\mathrm{a}}$ & 1.09 & 0.49 & 0.10 & -0.11 & 0.08 & 0.19 & 0.58 & 1.00 & & & & & & & & & & & & & & \\
\hline 7 Firm age & 3.62 & 4.02 & 0.11 & 0.22 & 0.33 & 0.17 & -0.02 & -0.15 & 1.00 & & & & & & & & & & & & & \\
\hline 8 \# of ET members & 2.11 & 1.43 & -0.19 & -0.12 & -0.04 & 0.06 & -0.03 & 0.00 & -0.20 & 1.00 & & & & & & & & & & & & \\
\hline 9 Prior founding experience & 0.21 & 0.41 & 0.10 & 0.15 & 0.07 & 0.12 & 0.15 & 0.05 & -0.02 & 0.14 & 1.00 & & & & & & & & & & & \\
\hline 10 Intangible assets ratio & 22.72 & 27.90 & -0.13 & -0.23 & -0.28 & -0.20 & -0.05 & 0.14 & -0.19 & 0.03 & -0.14 & 1.00 & & & & & & & & & & \\
\hline 11 Performance "proofpoint" & 0.37 & 0.48 & 0.09 & 0.01 & 0.07 & 0.09 & -0.03 & 0.02 & -0.15 & 0.13 & -0.02 & -0.02 & 1.00 & & & & & & & & & \\
\hline 12 VC size ${ }^{a}$ & 10.53 & 1.33 & 0.23 & 0.18 & 0.26 & 0.13 & 0.59 & 0.20 & 0.11 & -0.19 & 0.05 & -0.28 & -0.03 & 1.00 & & & & & & & & \\
\hline 13 VC age & 8.59 & 6.66 & 0.07 & 0.08 & 0.17 & 0.12 & 0.44 & 0.34 & -0.03 & -0.07 & 0.10 & -0.19 & -0.05 & 0.40 & 1.00 & & & & & & & \\
\hline 14 Government-related VC & 0.31 & 0.46 & 0.10 & 0.24 & 0.03 & -0.23 & 0.03 & -0.24 & 0.25 & -0.28 & 0.00 & -0.34 & 0.00 & 0.53 & 0.16 & 1.00 & & & & & & \\
\hline 15 University-related VC & 0.18 & 0.38 & -0.13 & -0.19 & -0.17 & -0.07 & -0.17 & 0.12 & -0.33 & 0.23 & -0.16 & 0.26 & 0.01 & -0.36 & -0.07 & -0.31 & 1.00 & & & & & \\
\hline 16 Syndication & 0.67 & 1.16 & 0.04 & -0.02 & 0.09 & 0.21 & 0.17 & 0.17 & -0.02 & -0.02 & -0.02 & 0.06 & 0.05 & 0.09 & 0.07 & -0.22 & -0.03 & 1.00 & & & & \\
\hline 17 High-tech dummy & 0.41 & 0.49 & 0.01 & -0.10 & 0.14 & 0.27 & 0.24 & 0.36 & -0.02 & 0.10 & 0.18 & 0.12 & -0.02 & -0.08 & -0.12 & -0.46 & 0.08 & 0.29 & 1.00 & & & \\
\hline 18 Industry peer growth (1) & 1.01 & 0.04 & 0.06 & -0.02 & 0.13 & 0.13 & 0.05 & 0.12 & 0.01 & 0.02 & -0.02 & 0.01 & 0.03 & 0.01 & -0.03 & -0.02 & 0.02 & 0.06 & 0.04 & 1.00 & & \\
\hline 19 Industry peer growth (2) & 1.02 & 0.10 & 0.14 & 0.00 & 0.11 & 0.13 & 0.04 & 0.15 & 0.01 & 0.02 & -0.01 & 0.01 & 0.03 & 0.00 & -0.01 & -0.01 & 0.14 & 0.01 & 0.09 & 0.53 & 1.00 & \\
\hline 20 Industry density ${ }^{a}$ & 6.36 & 1.61 & -0.18 & -0.13 & -0.32 & -0.33 & -0.04 & -0.01 & 0.02 & -0.08 & -0.12 & 0.07 & 0.07 & 0.07 & -0.01 & 0.14 & -0.16 & -0.01 & -0.20 & -0.04 & -0.23 & 1.00 \\
\hline 21 Average age industry peers & 11.83 & 4.73 & 0.00 & 0.19 & 0.21 & 0.09 & 0.03 & -0.12 & 0.19 & -0.11 & 0.01 & -0.21 & -0.04 & 0.13 & 0.06 & 0.23 & -0.13 & -0.07 & -0.32 & 0.04 & 0.05 & -0.46 \\
\hline
\end{tabular}

Note. Correlations lager than $|0.08|$ are significant at $\mathrm{p}<0.05$.

${ }^{a}$ indicates variables are log-transformed.

Variables 9, 11, 14, 15 and 17 are binary; hence, their correlations should be interpreted with care. Variable 18 represents industry peer growth rate in terms of total financial capital raised (used in models with financial resources as dependent variable), while variable 19 represents industry peer growth rate in terms of total employment (used in models with human resources as dependent variable). 
Table 2: GEE models of resource attraction

\begin{tabular}{|c|c|c|c|c|c|c|c|c|}
\hline \multirow{3}{*}{ Variables } & \multicolumn{4}{|c|}{ Financial resources } & \multicolumn{4}{|c|}{ Human resources } \\
\hline & \multicolumn{2}{|c|}{$\begin{array}{c}\text { Ln(Total } \\
\text { financial capital) }\end{array}$} & \multicolumn{2}{|c|}{$\begin{array}{c}\text { Ln(Debt } \\
\text { financing) }\end{array}$} & \multicolumn{2}{|c|}{$\begin{array}{l}\text { Ln(Total \# of } \\
\text { employees) }\end{array}$} & \multicolumn{2}{|c|}{$\begin{array}{c}\text { Ln(\# of skilled } \\
\text { employees) }\end{array}$} \\
\hline & M1 & M2 & M3 & M4 & M5 & M6 & M7 & M8 \\
\hline VC media prominence & - & $\begin{array}{c}0.15 \\
(0.16)\end{array}$ & - & $\begin{array}{c}0.40 \\
(0.31)\end{array}$ & - & $\begin{array}{c}0.15^{* * *} \\
(0.07)\end{array}$ & - & $\begin{array}{l}0.18^{*} \\
(0.11)\end{array}$ \\
\hline VC industry-specific experience & - & $\begin{array}{c}0.59 * * * \\
(0.17)\end{array}$ & - & $\begin{array}{c}0.67 * * \\
(0.32)\end{array}$ & - & $\begin{array}{c}0.03 \\
(0.07)\end{array}$ & - & $\begin{array}{c}0.05 \\
(0.11)\end{array}$ \\
\hline Lagged dependent variable & $\begin{array}{c}0.88 * * * \\
(0.04)\end{array}$ & $\begin{array}{c}0.88 * * * \\
(0.04)\end{array}$ & $\begin{array}{c}0.76^{* * * *} \\
(0.03)\end{array}$ & $\begin{array}{c}0.79 * * * \\
(0.03)\end{array}$ & $\begin{array}{c}0.96 * * * \\
(0.03)\end{array}$ & $\begin{array}{c}0.96 * * * \\
(0.03)\end{array}$ & $\begin{array}{c}0.81 * * * \\
(0.03)\end{array}$ & $\begin{array}{c}0.80 * * * \\
(0.03)\end{array}$ \\
\hline Lagged total financial capital & - & - & - & - & $\begin{array}{l}-0.01 \\
(0.01)\end{array}$ & $\begin{array}{l}-0.01 \\
(0.01)\end{array}$ & $\begin{array}{c}0.00 \\
(0.02)\end{array}$ & $\begin{array}{l}-0.00 \\
(0.02)\end{array}$ \\
\hline Lagged total \# of employees & $\begin{array}{c}0.17 * * * \\
(0.06)\end{array}$ & $\begin{array}{c}0.18 * * * \\
(0.06)\end{array}$ & $\begin{array}{c}0.04 \\
(0.11)\end{array}$ & $\begin{array}{c}0.02 \\
(0.10)\end{array}$ & - & - & - & - \\
\hline Firm age & $\begin{array}{c}0.00 \\
(0.02)\end{array}$ & $\begin{array}{l}-0.00 \\
(0.02)\end{array}$ & $\begin{array}{c}0.00 \\
(0.03)\end{array}$ & $\begin{array}{l}-0.00 \\
(0.03)\end{array}$ & $\begin{array}{l}-0.01 \\
(0.01)\end{array}$ & $\begin{array}{l}-0.01 \\
(0.01)\end{array}$ & $\begin{array}{c}0.00 \\
(0.01)\end{array}$ & $\begin{array}{c}0.00 \\
(0.01)\end{array}$ \\
\hline \# of ET members & $\begin{array}{l}-0.01 \\
(0.04)\end{array}$ & $\begin{array}{l}-0.01 \\
(0.04)\end{array}$ & $\begin{array}{l}-0.03 \\
(0.08)\end{array}$ & $\begin{array}{l}-0.04 \\
(0.08)\end{array}$ & $\begin{array}{l}-0.01 \\
(0.02)\end{array}$ & $\begin{array}{l}-0.02 \\
(0.02)\end{array}$ & $\begin{array}{c}0.01 \\
(0.03)\end{array}$ & $\begin{array}{l}-0.00 \\
(0.03)\end{array}$ \\
\hline Prior founding experience & $\begin{array}{c}0.05 \\
(0.14)\end{array}$ & $\begin{array}{c}0.04 \\
(0.13)\end{array}$ & $\begin{array}{l}0.50 * \\
(0.28)\end{array}$ & $\begin{array}{l}0.45^{*} \\
(0.25)\end{array}$ & $\begin{array}{c}0.02 \\
(0.06)\end{array}$ & $\begin{array}{c}0.02 \\
(0.06)\end{array}$ & $\begin{array}{c}0.06 \\
(0.09)\end{array}$ & $\begin{array}{c}0.06 \\
(0.09)\end{array}$ \\
\hline Intangible assets ratio & $\begin{array}{l}-0.00 \\
(0.00)\end{array}$ & $\begin{array}{l}-0.00 \\
(0.00)\end{array}$ & $\begin{array}{l}-0.00 \\
(0.00)\end{array}$ & $\begin{array}{l}-0.00 \\
(0.00)\end{array}$ & $\begin{array}{c}-0.00 \\
(0.00)\end{array}$ & $\begin{array}{c}-0.00 \\
(0.00)\end{array}$ & $\begin{array}{l}-0.00 \\
(0.00)\end{array}$ & $\begin{array}{l}-0.00 \\
(0.00)\end{array}$ \\
\hline Performance "proofpoint" & $\begin{array}{c}0.28 * * \\
(0.11)\end{array}$ & $\begin{array}{c}0.30 * * * \\
(0.11)\end{array}$ & $\begin{array}{c}0.26 \\
(0.18)\end{array}$ & $\begin{array}{c}0.23 \\
(0.18)\end{array}$ & $\begin{array}{c}0.14 * * * \\
(0.04)\end{array}$ & $\begin{array}{c}0.14^{* * *} \\
(0.04)\end{array}$ & $\begin{array}{c}0.06 \\
(0.05)\end{array}$ & $\begin{array}{c}0.06 \\
(0.05)\end{array}$ \\
\hline VC size & $\begin{array}{l}-0.03 \\
(0.06)\end{array}$ & $\begin{array}{c}-0.13^{* *} \\
(0.06)\end{array}$ & $\begin{array}{c}0.00 \\
(0.11)\end{array}$ & $\begin{array}{c}-0.17 \\
(0.13)\end{array}$ & $\begin{array}{c}0.02 \\
(0.02)\end{array}$ & $\begin{array}{l}-0.02 \\
(0.03)\end{array}$ & $\begin{array}{c}0.01 \\
(0.04)\end{array}$ & $\begin{array}{l}-0.04 \\
(0.04)\end{array}$ \\
\hline VC age & $\begin{array}{c}0.00 \\
(0.01)\end{array}$ & $\begin{array}{l}-0.01 \\
(0.01)\end{array}$ & $\begin{array}{l}-0.02 \\
(0.02)\end{array}$ & $\begin{array}{c}-0.04 * * \\
(0.02)\end{array}$ & $\begin{array}{l}-0.00 \\
(0.00)\end{array}$ & $\begin{array}{l}-0.00 \\
(0.00)\end{array}$ & $\begin{array}{c}0.00 \\
(0.01)\end{array}$ & $\begin{array}{l}-0.00 \\
(0.01)\end{array}$ \\
\hline Government-related VC & $\begin{array}{c}0.09 \\
(0.18)\end{array}$ & $\begin{array}{l}0.28 * \\
(0.17)\end{array}$ & $\begin{array}{c}0.01 \\
(0.35)\end{array}$ & $\begin{array}{c}0.24 \\
(0.33)\end{array}$ & $\begin{array}{l}-0.07 \\
(0.07)\end{array}$ & $\begin{array}{l}-0.03 \\
(0.07)\end{array}$ & $\begin{array}{l}-0.18 \\
(0.11)\end{array}$ & $\begin{array}{l}-0.13 \\
(0.12)\end{array}$ \\
\hline University-related VC & $\begin{array}{c}0.04 \\
(0.18)\end{array}$ & $\begin{array}{l}-0.13 \\
(0.17)\end{array}$ & $\begin{array}{l}-0.14 \\
(0.35)\end{array}$ & $\begin{array}{l}-0.36 \\
(0.33)\end{array}$ & $\begin{array}{l}-0.03 \\
(0.07)\end{array}$ & $\begin{array}{l}-0.04 \\
(0.08)\end{array}$ & $\begin{array}{l}-0.00 \\
(0.11)\end{array}$ & $\begin{array}{l}-0.01 \\
(0.11)\end{array}$ \\
\hline Syndication & $\begin{array}{c}-0.09 * \\
(0.05)\end{array}$ & $\begin{array}{c}-0.10 * * \\
(0.05)\end{array}$ & $\begin{array}{l}-0.09 \\
(0.10)\end{array}$ & $\begin{array}{l}-0.10 \\
(0.09)\end{array}$ & $\begin{array}{c}-0.04^{*} \\
(0.02)\end{array}$ & $\begin{array}{c}-0.04^{*} \\
(0.02)\end{array}$ & $\begin{array}{l}-0.01 \\
(0.03)\end{array}$ & $\begin{array}{l}-0.01 \\
(0.03)\end{array}$ \\
\hline High tech firm & $\begin{array}{c}0.15 \\
(0.37)\end{array}$ & $\begin{array}{l}-0.22 \\
(0.35)\end{array}$ & $\begin{array}{c}-1.22 * \\
(0.73)\end{array}$ & $\begin{array}{c}-1.67 * * \\
(0.69)\end{array}$ & $\begin{array}{c}-0.24 \\
(0.15)\end{array}$ & $\begin{array}{c}-0.32 * * \\
(0.15)\end{array}$ & $\begin{array}{l}-0.11 \\
(0.23)\end{array}$ & $\begin{array}{l}-0.21 \\
(0.24)\end{array}$ \\
\hline Industry peer growth & $\begin{array}{l}-1.70 \\
(1.54)\end{array}$ & $\begin{array}{l}-1.72 \\
(1.52)\end{array}$ & $\begin{array}{l}-3.73 \\
(2.48)\end{array}$ & $\begin{array}{l}-3.31 \\
(2.49)\end{array}$ & $\begin{array}{c}0.61 * * * \\
(0.22)\end{array}$ & $\begin{array}{c}0.60 * * * \\
(0.22)\end{array}$ & $\begin{array}{l}0.45^{*} \\
(0.24)\end{array}$ & $\begin{array}{l}0.45^{*} \\
(0.24)\end{array}$ \\
\hline Industry density & $\begin{array}{l}-0.05 \\
(0.05)\end{array}$ & $\begin{array}{c}-0.11^{* *} \\
(0.05)\end{array}$ & $\begin{array}{l}-0.03 \\
(0.10)\end{array}$ & $\begin{array}{l}-0.14 \\
(0.10)\end{array}$ & $\begin{array}{c}0.02 \\
(0.02)\end{array}$ & $\begin{array}{c}0.01 \\
(0.02)\end{array}$ & $\begin{array}{c}0.00 \\
(0.03)\end{array}$ & $\begin{array}{l}-0.01 \\
(0.03)\end{array}$ \\
\hline Average age industry peers & $\begin{array}{l}-0.02 \\
(0.02)\end{array}$ & $\begin{array}{c}-0.04 * * \\
(0.02)\end{array}$ & $\begin{array}{c}0.01 \\
(0.04)\end{array}$ & $\begin{array}{l}-0.02 \\
(0.03)\end{array}$ & $\begin{array}{c}0.01 \\
(0.01)\end{array}$ & $\begin{array}{c}0.01 \\
(0.01)\end{array}$ & $\begin{array}{c}0.01 \\
(0.01)\end{array}$ & $\begin{array}{c}0.01 \\
(0.01)\end{array}$ \\
\hline Number of observations & 415 & 415 & 415 & 415 & 411 & 411 & 417 & 417 \\
\hline Number of firms & 94 & 94 & 94 & 94 & 94 & 94 & 94 & 94 \\
\hline Chi square & $1259 * * *$ & $1513 * * *$ & $796.3 * * *$ & $963.2 * * *$ & $2975 * * *$ & $3107 * * *$ & $1309 * * *$ & $1343 * * *$ \\
\hline
\end{tabular}

Note . All models include a constant, industry fixed effects, accounting year fixed effects and investment year fixed effects (not reported due to space considerations). ${ }^{* * *} \mathrm{p}<0.01,{ }^{* *} \mathrm{p}<0.05, * \mathrm{p}<0.10$ (Conservative two-tailed tests). 
Table 3: GEE models of resource attraction, sample split by firm industry and age

\begin{tabular}{|c|c|c|c|c|c|c|c|c|}
\hline \multirow[t]{3}{*}{ Panel A } & \multicolumn{4}{|c|}{ Biotechnology and ICT firms } & \multicolumn{4}{|c|}{ Other firms } \\
\hline & \multicolumn{2}{|c|}{ Financial resources } & \multicolumn{2}{|c|}{ Human resources } & \multicolumn{2}{|c|}{ Financial resources } & \multicolumn{2}{|c|}{ Human resources } \\
\hline & $\begin{array}{c}\text { Ln(Total } \\
\text { financial } \\
\text { capital) }\end{array}$ & $\begin{array}{l}\text { Ln(Debt } \\
\text { financing) }\end{array}$ & $\begin{array}{c}\text { Ln(Total \# of } \\
\text { employees) }\end{array}$ & $\begin{array}{l}\text { Ln(\# of skilled } \\
\text { employees) }\end{array}$ & $\begin{array}{l}\text { Ln(Total } \\
\text { financial } \\
\text { capital) }\end{array}$ & $\begin{array}{l}\mathrm{Ln}(\text { Debt } \\
\text { financing) }\end{array}$ & $\begin{array}{c}\text { Ln(Total \# of } \\
\text { employees) }\end{array}$ & $\begin{array}{c}\text { Ln(\# of skilled } \\
\text { employees) }\end{array}$ \\
\hline VC media prominence & $\begin{array}{c}0.50 * * * \\
(0.18)\end{array}$ & $\begin{array}{l}-0.29 \\
(0.30)\end{array}$ & $\begin{array}{c}0.14^{* *} \\
(0.06)\end{array}$ & $\begin{array}{c}0.33 * * * \\
(0.13)\end{array}$ & $\begin{array}{l}-0.03 \\
(0.23)\end{array}$ & $\begin{array}{c}0.25 \\
(0.47)\end{array}$ & $\begin{array}{c}0.07 \\
(0.09)\end{array}$ & $\begin{array}{c}0.09 \\
(0.10)\end{array}$ \\
\hline VC industry-specific experience & $\begin{array}{c}0.70 * * * \\
(0.22)\end{array}$ & $\begin{array}{c}1.46^{* * *} \\
(0.37)\end{array}$ & $\begin{array}{l}-0.10 \\
(0.07)\end{array}$ & $\begin{array}{l}-0.06 \\
(0.16)\end{array}$ & $\begin{array}{c}0.57 * * \\
(0.24)\end{array}$ & $\begin{array}{c}0.68 \\
(0.50)\end{array}$ & $\begin{array}{l}-0.01 \\
(0.10)\end{array}$ & $\begin{array}{c}0.05 \\
(0.11)\end{array}$ \\
\hline Control variables & Included & Included & Included & Included & Included & Included & Included & Included \\
\hline Number of observations & 141 & 141 & 139 & 144 & 274 & 274 & 272 & 273 \\
\hline Number of firms & 34 & 34 & 34 & 34 & 60 & 60 & 60 & 60 \\
\hline Chi square & $1423 * * *$ & $931.4 * * *$ & $9250 * * *$ & $845.4^{* * *}$ & $963.3 * * *$ & $622.1 * * *$ & $2588 * * *$ & $1822 * * *$ \\
\hline \multirow[t]{3}{*}{ Panel B } & \multicolumn{4}{|c|}{ Younger firms } & \multicolumn{4}{|c|}{ Older firms } \\
\hline & \multicolumn{2}{|c|}{ Financial resources } & \multicolumn{2}{|c|}{ Human resources } & \multicolumn{2}{|c|}{ Financial resources } & \multicolumn{2}{|c|}{ Human res ources } \\
\hline & $\begin{array}{c}\text { Ln(Total } \\
\text { financial } \\
\text { capital) }\end{array}$ & $\begin{array}{l}\operatorname{Ln}(\text { Debt } \\
\text { financing) }\end{array}$ & $\begin{array}{c}\text { Ln(Total \# of } \\
\text { employees) }\end{array}$ & $\begin{array}{l}\text { Ln(\# of skilled } \\
\text { employees) }\end{array}$ & $\begin{array}{c}\text { Ln(Total } \\
\text { financial } \\
\text { capital) }\end{array}$ & $\begin{array}{l}\text { Ln(Debt } \\
\text { financing) }\end{array}$ & $\begin{array}{c}\text { Ln(Total \# of } \\
\text { employees) }\end{array}$ & $\begin{array}{c}\text { Ln(\# of skilled } \\
\text { employees) }\end{array}$ \\
\hline VC media prominence & $\begin{array}{l}-0.05 \\
(0.16)\end{array}$ & $\begin{array}{l}-0.17 \\
(0.34)\end{array}$ & $\begin{array}{c}0.19 * * \\
(0.10)\end{array}$ & $\begin{array}{l}0.22 * \\
(0.13)\end{array}$ & $\begin{array}{l}-0.03 \\
(0.17)\end{array}$ & $\begin{array}{c}0.53 \\
(0.42)\end{array}$ & $\begin{array}{c}0.01 \\
(0.08)\end{array}$ & $\begin{array}{c}0.06 \\
(0.11)\end{array}$ \\
\hline VC industry-specific experience & $\begin{array}{c}0.48 * * \\
(0.20)\end{array}$ & $\begin{array}{c}1.34 * * * \\
(0.43)\end{array}$ & $\begin{array}{c}0.09 \\
(0.12)\end{array}$ & $\begin{array}{c}0.16 \\
(0.15)\end{array}$ & $\begin{array}{c}0.43 * * \\
(0.20)\end{array}$ & $\begin{array}{l}-0.33 \\
(0.47)\end{array}$ & $\begin{array}{l}-0.09 \\
(0.09)\end{array}$ & $\begin{array}{l}-0.14 \\
(0.13)\end{array}$ \\
\hline Control variables & Included & Included & Included & Included & Included & Included & Included & Included \\
\hline Number of observations & 180 & 180 & 178 & 178 & 235 & 235 & 233 & 239 \\
\hline Number of firms & 44 & 44 & 44 & 44 & 50 & 50 & 50 & 50 \\
\hline Chi square & $5489 * * *$ & $1113^{* * *}$ & $1800 * * *$ & $1040 * * *$ & $742.7 * * *$ & $525.2 * * *$ & $2353 * * *$ & $1241 * * *$ \\
\hline
\end{tabular}

Note. All models include the control variables reported in Table 2, a constant, industry fixed effects, accounting year fixed effects and investment year fixed effects (not reported due to space considerations). ${ }^{* * *} \mathrm{p}<0.01,{ }^{* *} \mathrm{p}<0.05$, ${ }^{*} \mathrm{p}<0.10$ (Conservative two-tailed tests). 